\title{
10.2 Соціальна політика як елемент ітегрального механізму покращення якості життя населення України
}

Підвищення значення соціальної політики сприяє поліпшенню якості життя суспільства. Узгодження інтересів суспільства $є$ складним та багатоаспектним процесом, що охоплює різні процеси, обгрунтовує необхідність використання можливостей соціальної політики. Однією з складових місії $є$ задоволення споживчих потреб суспільства. Лише вивчивши цінності та потреби, можна стверджувати, що соціальна політика має визначені основи $\mathrm{i}$ напрямки, які слід брати до уваги при розробці стратегій соціальної політики на різних рівнях іiі регулювання. Тобто, соціальна політика держави відповідає вимогам населення тільки тоді, коли іiі формування відбулося на основі сформованої соціальної політики регіону, що, у свою чергу, грунтується на досвіді формування соціальної політики підприємств, які належать до різних сфер людської діяльності. Тому, дослідження проблематики формування соціальної політики має актуальне значення.

Проблеми формування соціальної політики розглядаються в працях багатьох вітчизняних та інших визнанених вчених: В. Гриньової, А. Ягідки, В. Пономаренка, В. Скуратівського, Е. Холостової, І. Багрової, І. Григор'євої, М. Дороніної, М. Кизима, Н. Бар'я, Н. Волгіна, Н. Гілберта,Н. Горелова, Н. Лисиці, О. Іванової, О. Новикової, П. Спікера, С. Бульбенюка, С. Гончарової, С. Смирнова, С. Тетерського,Т. Ганслі, Ш. Рамона та інших, а проблемам оцінювання реальних доходів населення й регулюванню соціаль-них стандартів присвятили свої дослідження такі вітчизняні вчені: А. Колот, А. Костишина,
В. Загорський,
В. Литвинов,
В. Мандибура,
Г. Завіновська,
Г. Куліков, Д. Богиня, Е. Лібанова, І. Білоус, І. Гнибіденко, І. Новак, І. Ротчук, К. Ковазіна, Л. Черенько М. Крупка, М. Лазебна, М. Соколик, Н. Коваль, Н. Федірко, О. Базилюк, О. Бистрицька, О. Варецька, О. Жук, О. Мельниченко, П. Герасименко, С. Борлуцький, С. Мірошниченко, та інші. Певні аспекти цієї проблематики досліджували науковці ближнього та дальнього зарубіжжя: Л. Абалкін, А. Аганбегян, М. Волков, М. Мейксін, В. Логінова, А. Ощепков, 
Л. Степанова, Л. Яковлєва та інші, а також Н. Больц, Дж. Гікс, А. Дейтон, С. Клейн, О. Лоренц, Г. Патлер, О. Руф-Фідлер та інші. Разом з тим, є багато питань, які потребують постійного дослідження та уточнення, а саме: недостатньо чітко розділявся зміст соціальної та економічної політики; трактування змісту соціальної політики, як правило, обмежуються рамками проблем щодо забезпечення соціального захисту населення; сфера соціальної політики у більшості випадків, обмежувалася вирішення вузького кола проблем; соціальна політика розглядалася тільки в рамках соціальної відповідальності; наявні проблеми щодо узгодженості нормативно-правового забезпечення даної сфери.

Об’єктом дослідження $є$ процес формування соціальної політики у контексті забезпечення відповідного рівня та якості життя населення, а предметом - теоретичні і методичні аспекти формування соціальної політики України. Теоретичною основою дослідження послужили: законодавчі акти та нормативні документи за темою роботи; базова навчальна література; теоретичні праці вчених, що досліджували дану проблематику; статті в спеціалізованих і періодичних виданнях, які висвітлюють проблеми соціальної політики; довідкова література; статистична інформація; інформаційні бази мережі Інтернет. Обрана для розгляду проблема обумовлена, з одного боку, достатньо високим інтересом до особливостей здійснення соціальної політики у сучасній науці, а $з$ іншого боку - іiі недостатньою розробленістю. Практичне значення дослідження полягає в тому, що здійснено оцінку стану формування та реалізації соціальної політики в контексті забезпечення відповідного рівня якості життя. Дослідження даної теми іï висвітлення у трьох розділах.

Розділ 1. Обгрунтування теоретичних засад формування та здійснення соціальної політики. Вирішення проблем, які пов'язані із функціонуванням соціальної сфери, є прерогативою будь-якої держави. Крім того, соціальна сфера є підсистема національної економіки, тобто це явища, процеси, види діяльності та об'єкти, що мають зв'язок щодо забезпечення життєдіяльності суспільства, 
людини, задоволенням їх потреб та інтересів.

Єдності серед науковців щодо визначення поняття «соціальна політика» не має. Вони трактують дане поняття таким чином:

- «Соціальна політика - діяльність держави щодо створення та регулювання соціально-економічних умов життя суспільства 3 метою підвищення добробуту членів суспільства, усунення негативних наслідків функціонування ринкових процесів, забезпечення соціальної справедливості та соціально-політичної стабільності у країні [543, с. 288]»;

- «Соціальна політика - система правових, організаційних, регулятивноконтрольних заходів держави з метою узгодження цілей соціального характеру із цілями економічного зростання [544, с. 21]»;

- «Соціальна політика - один із видів регулювання держави, яка називається державою загального добробуту та взяла на себе обов'язки забезпечувати певний добробут населення, і включає програми, служби та заходи, що переслідують соціальні цілі, охоплюючи різноманітні сфери життєдіяльності членів суспільства (виробничу, духовну, побутову), регулюючи стосунки між суспільством, колективом, особою не тільки у кожній із цих сфер, але й і в зонах їхньої взаємодії $[559$, с. 10]».

В. А. Скуратівський пропонує розрізняти «вузьке та широке розуміння соціальної політики: у вузькому розумінні соціальна політика - це діяльність суб'єктів соціально-політичного життя, спрямована на формування соціальної безпеки людини й суспільства»; у широкому розумінні - це система інституційних i надінституційних, державних i громадських, суспільних i особистих, індивідуальних способів і форм діяльності, спрямованих на створення умов для всебічної самореалізації соціального потенціалу людини, iї сутнісних сил [538, с. 5]». М. А. Волгін стверджував, що «соціальна політика це взаємини соціальних груп із приводу збереження й зміни соціального стану населення в цілому й складових його класів, шарів, соціальних, соціальнодемографічних, соціально-професійних груп, соціальних общин (родини, народу, селища, міста, регіону й т.п.) [542, с. 14]». С. І. Холостова зазначає, що 
«соціальна політика являє собою проведену державними структурами, громадськими організаціями, органами місцевого самоврядування, а також виробничими колективами систему заходів, спрямованих на досягнення соціальних цілей $\mathrm{i}$ результатів, пов'язаних 3 підвищенням суспільного добробуту, поліпшенням якості життя народу й забезпеченням соціальнополітичної стабільності, соціального партнерства в суспільстві» [556, с. 12].

На рисунку 10.2.1 представлена суть соціальної політики, яка включає в себе зміст і цілі соціальної політики, іiї об’єкти і суб’єкти, функції і завдання, принципи соціальної політики, їі механізми та інструменти.

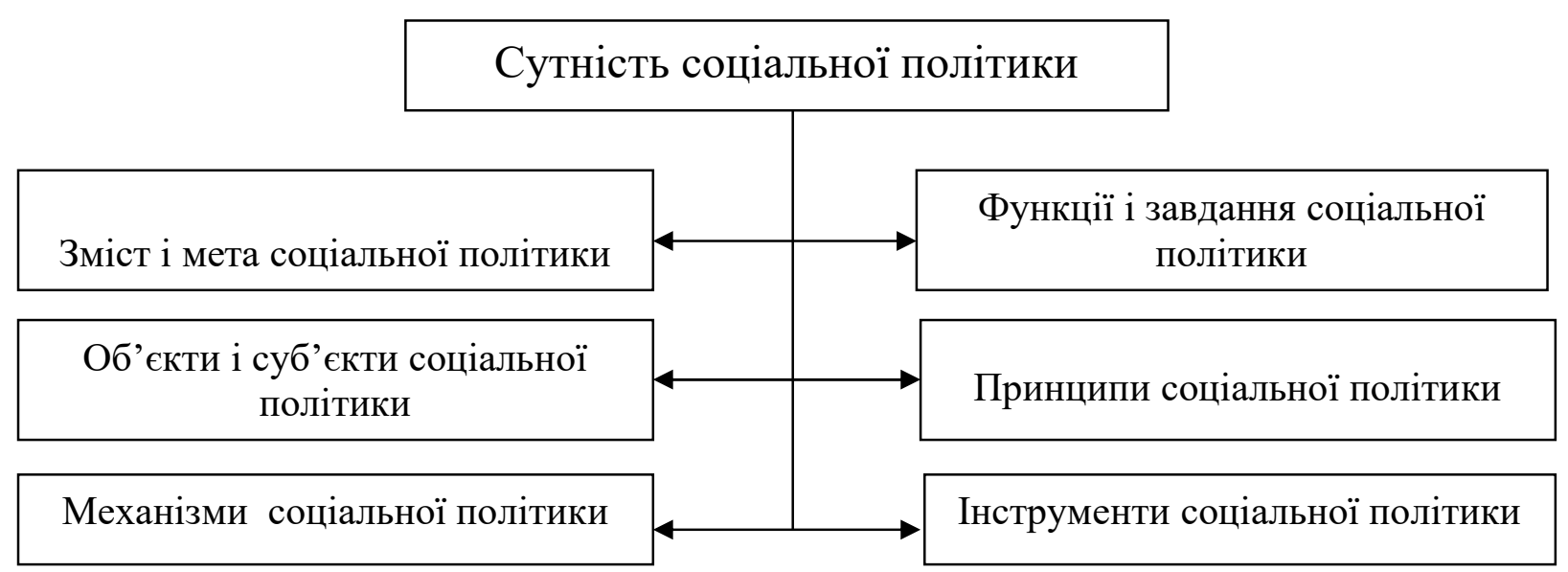

Рис. 10.2.1. Сутність соціальної політики

Джерело: [511], власне узагальнення

Головною метою соціальної політики, перш за усе, $є$ створення передумов для посилення рівня суспільного соціального захисту та соціальної безпеки, досягнення соціальної злагоди, стабільності та соціальної цілісності.

На думку О. Колишкіна О. [511] соціальна політика має передбачати досягнення певної мети. Ми переконані, що нижче наведені напрями досягнення мети мають найактуальніше значення:

- забезпечення стабільного функціонування суспільства, тобто суспільства стабільного, без заворушень і потрясінь, у якому є можливість досягнути суспільної злагоди та цілісності, достойного рівня життєдіяльності населення;

- забезпечення розвитку особистості шляхом можливості вільно розвивати та реалізовувати свої здібності, а також одержувати достойний дохід, 
поліпшувати власний добробут;

- досягнення достойного рівня життєдіяльності людей, а саме - соціального рівня та якості життя, що є прийнятним; соціального захисту категорії малозабезпечене населення та їх безпеки у соціальному плані в суспільстві.

Це означає, що основою соціальної політики має бути максимальне збереження потенціалу людини i країни (фізичного, інтелектуального, духовного-етичного); формування трудової мотивації, виходячи з вимог ринку та соціально-орієнтованої економіки країни; створення та реалізація інституційних та соціально-економічних передумов, які б сприяли розвитку людини, активізували іiї трудову діяльності, гарантували усі ії права та свободи.

У своїй статті О. Іванова [509] сформулювала перелік завдань до соціальної політики. До першочергових завдань, на нашу думку, варто віднести наступні:

- шляхом застосування різних форм компенсації від негативних економічних явищ захисти рівень життя населення;

- надання найбіднішим сім'ям певних допомог;

- надання допомоги при втраті роботи;

- проведення політики соціального страхування;

- встановлення мінімальної гарантованої заробітної плати для працюючих на законодавчому рівні;

- розвиток освітньої, медичної та природоохоронної сфери за рахунок державних коштів;

- здійснення активної політики, яка спрямована на отримання певної кваліфікації громадянами.

На рисунку 10.2..2 окреслене основне коло функцій, тобто головних суспільних завдань та напрямків, соціальної політики. 


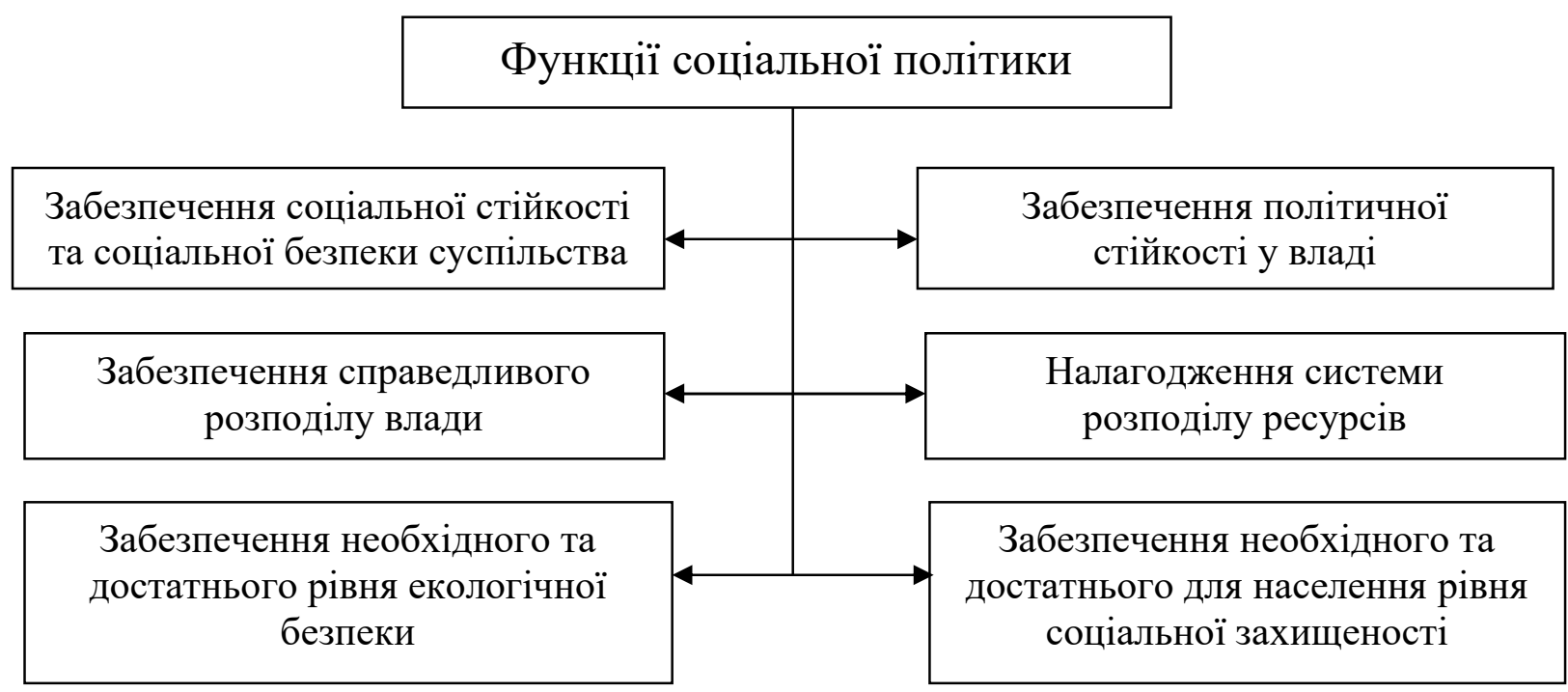

\section{Рис. 10.2.2. Функції соціальної політики}

Джерело: [515], власне узагальнення.

Досліджуючи характеристики основних функцій соціальної політики, ми встановили наступне:

1) функція забезпечення соціальної стійкості суспільства та соціальної безпеки суспільства означає, що соціальна структура може бути різною в різних суспільствах. Крім того, вона є якісно мінливою в історії одного й того ж суспільства в результаті значних революційних нововведень, але вона повинна мати властивості стійкості й динамічного розвитку (інакше дане суспільство руйнується та може припинити існування). Соціальна структура, через свою стійкість, має витримати внутрішні і зовнішні небезпеки іiі руйнування, а також мати перспективу й потенціал якісного відновлення шляхом реформ і революцій;

2) функція забезпечення політичної стійкості у владі означає, що така стійкість може бути досягнута в суспільствах різного типу та у різних індивідуальних історичних умовах по-різному, але суть завжди зводиться до такого - розподіл реальної участі соціальних класів або груп у політичних рішеннях для стримування домінуючого впливу у владі того ж самого панівного класу. Інакше відбувається зміна класового типу влади та можуть настати неминучі революційні перетворення, а серед цих перетворень у пріоритеті має бути забезпечення політичної стійкості, але вже нової влади;

3) функція забезпечення справедливого розподілу влади означає, що 
розподіл владних повноважень має бути справедливим, не потребувати боротьби за його переділ;

4) функція налагодження системи розподілу ресурсів означає, що цей розподіл має влаштовувати переважну більшість населення, оскільки від цього розподілу у певному розумінні залежать умови матеріального забезпечення життя людей у суспільстві, а також можливості рішення проблем різних соціальних груп. До економічних параметрів, які мають соціальний сенс i соціальне призначення, належать такі: інвестиції і їхня структура; рівень i диференціювання доходів; загальний розмір та структура соціальних витрат за річний період; умови й розміри соціальної допомоги й підтримки;

5) функція забезпечення необхідного та достатнього рівня екологічної безпеки належить до актуальних функцій соціальної політики, оскільки пов'язана із забезпеченням суспільством і державою необхідного й достатнього рівня екологічної безпеки;

6) функція забезпечення необхідного та достатнього для населення рівня соціальної захищеності грунтується на тому, що держава, яка виступає як гарант та захисник для громадян країни, повинна створювати певну систему захисту для усього суспільства - як для економічно сильних членів суспільства, так і для слабких та вразливих верств населення.

На рисунку 10.2.3 наведені основні об'єкти соціальної політики.

\begin{tabular}{|c|c|}
\hline Об' & ітики \\
\hline $\begin{array}{c}\text { Ринок праці та зайнятість } \\
\text { населення }\end{array}$ & $\begin{array}{c}\text { Система соціального захисту } \\
\text { населення }\end{array}$ \\
\hline $\begin{array}{l}\text { Трудові } \\
\text { відносини }\end{array}$ & $\begin{array}{l}\text { Елементи соціальної } \\
\text { інфраструктури }\end{array}$ \\
\hline Громадяни як споживачі & $\begin{array}{c}\text { Оплата праці та доходи } \\
\text { населення }\end{array}$ \\
\hline
\end{tabular}

Рис. 10.2.3. Об'єкти соціальної політики

Джерело: власне узагальнення.

Т. Семигіна надала детальну характеристику об'єктам соціальної політики 
[533]. Досліджуючи характеристики основних об’єктів соціальної політики , ми встановили наступне:

1) ринок праці та зайнятість населення: ринок праці належить до факторів виробництва, коли домогосподарства (в ролі найманих працівників) пропонують свою працю, а виробники (працедавці) мають потребу в ній. У результаті згоди встановлюється ціна праці, яка є при цьому ставкою заробітної плати, та обсяг праці, що використовується. Щодо зайнятості населення, то це соціальноекономічна категорія, яка характеризується залученням населення в суспільне виробництво, від якого залежить рівень та якість життя, загальний соціальнопсихологічний стан суспільства та можливості реалізації здібностей людини, трудового потенціалу суспільства в цілому.

2) система соціального захисту населення включає в себе систему заходів, які мають захищати будь-якого громадянина країни від економічної та соціальної труднощів не тільки через втрату роботи (тобто безробіття), а також тоді, коли відбувається втрата чи різке скорочення доходів, або хвороби, виробничі травми чи інвалідність, досягнення похилого віку тощо;

3) як відомо, трудові відносини врегульовані нормами трудового права, а от суспільні відносини, які виникли у результаті впливу норм трудового права на поведінку суб'єктів трудової діяльності через укладання трудового договору, коли виникають правові зв'язки, а також через відносини щодо встановлення умов праці, навчання й перекваліфікації за місцем роботи та відносини, вирішенням конфліктів і трудових спорів та працевлаштуванням;

4) елементи соціальної інфраструктури формуються з тих галузей, які забезпечують нормальні умови життєдіяльності людей: роздрібна торгівля (забезпечує товарами народного споживання); громадське харчування (забезпечує продукцією харчування); житло; дитсадки та інші дошкільні заклади; заклади охорони здоров’я; заклади культури;

5) громадяни як споживачі є суб’єктами ринкової економіки та ключовою фігурою у взаємовідносинах між виробником та продавцем товарів, для якої працюють мільярди людей, створюючи товари різноманітного призначення. 
Громадяни мають право на гарантований рівень споживання, який забезпечується стимулюванням виробництва товарів, виконання робіт та надання послуг - це як споживачі, а також запровадженням компенсаційних виплат, різних допомог та пільг - це як громадянин;

6) оплата праці та доходи населення. Як відомо оплата праці (заробітна плата) являє собою винагороду, що має бути виплачена найманому працівникові роботодавцем за виконану ним роботу, то саме через систему заробітної плати суспільство здійснює мотивацію праці, контролює міру праці та міру споживання матеріальних i духовних благ працівниками. Під доходами населення розуміють суму грошових засобів і матеріальних благ, які були отриманими або створеними громадянами за певний часовий проміжок. Саме доходи є визначальними, оскільки рівень споживання населення прямо залежить від їх рівня.

Держава через відповідальних за формування та реалізацію соціальної політики органи законодавчої та виконавчої влади, до яких відносяться Верховна Рада України та Уряд з його профільними Міністерствами (праці та соціальної політики, охорони здоров'я, освіти і науки - є головним суб'єктом соціальної політики в Україні. Також до суб'єктів соціальної політики належать державні комітети й відомства та органи місцевого самоврядування. Активну роль у здійсненні соціальної політики відіграють громадські та політичні організації, профспілки, фонди та асоціації. Проте, серед інституціональних структур, які здійснюють соціальну політику, головну роль відіграє саме держава. Держава має виконувати координаційні та організаційні дії щодо регулювання процесів функціонування та розвитку соціального життя країни. За величиною потенціалу держава, що є суб'єктом соціальної політики, має значно більше можливостей у порівнянні з іншими суб' єктами цього процесу.

Отже, соціальна політика являє собою таку діяльність держави, яка передбачає створення та врегулювання соціально-економічних умов життя суспільства на засадах підвищення добробуту членів суспільства та усунення або мінімізації впливу негативних наслідків від розвитку ринкових процесів, а також 
забезпечення соцсправедливості та соціальної й політичної стабільності. Соціальна політики визначає суспільно-політичні та макроекономічні орієнтири, де перші визначаються обраною моделлю суспільної політики.

Діяльність держави, яка направлена на створення та регулювання соціально-економічних умов життя суспільства, що ставить за мету підвищення добробуту членів суспільства, мінімізацію або усунення негативних наслідків функціонування ринкових процесів, забезпечення справедливості та стабільності у соціальній та соціально-політичної сферах у країні називається соціальна політика. Соціальна політика повинна базуватися на певних принципах, що наведені на рисунку 10.2.4.

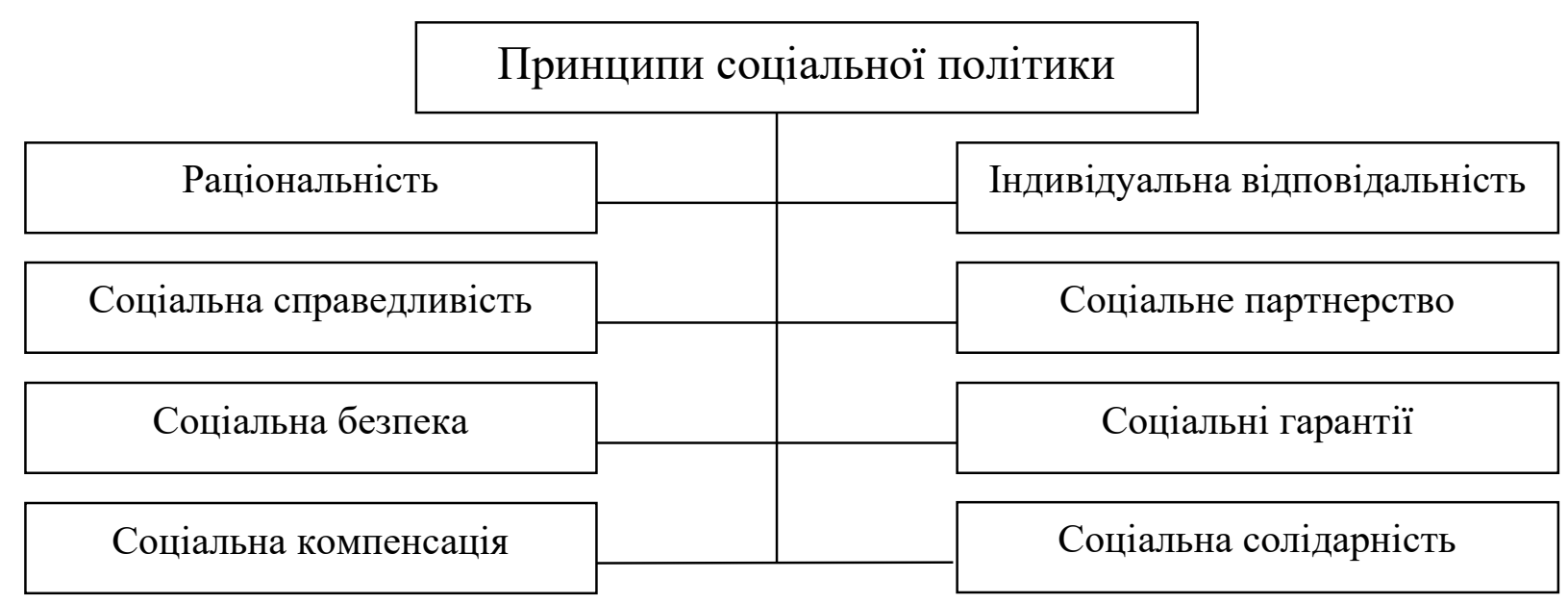

\section{Рис. 10.2.4. Принципи соціальної політики}

Джерело: [509], власне узагальнення.

Дослідимо характеристики даних принципів соціальної політики:

1) принцип раціональності передбачає досягнення найкращого співвідношення між метою соціальної політики та засобами ії реалізації, через адекватний розподіл фінансових засобів, соціальних інвестицій за різними напрямками з урахуванням пріоритетів;

2) принцип соціальної справедливості передбачає однакові можливості для всіх членів суспільства щодо можливостей вільного розвитку, реалізації своїх здібностей, одержання справедливого доходу, поліпшення добробуту, тобто забезпечення рівня та якості життя;

3) принцип соціальної безпеки передбачає наявність такого стану 
державного розвитку, коли держава має спроможна забезпечити гідний та якісний рівень життя населення, а вплив внутрішніх та зовнішніх загроз, при цьому, є мінімальним;

4) принцип соціальної компенсації має забезпечити часткову фінансову компенсацію, яка призначається непрацюючим особам, або соціальні послуги, які мають надаватися громадянам похилого віку, інвалідам, хворим, тобто тим, хто не здатен до самообслуговування й потребують постійної сторонньої допомоги;

5) принцип індивідуальної відповідальності пов’язаний із соціалізацією особистості, оскільки вона утверджується як новоутворення у період соціальної зрілості;

6) принцип соціального партнерства передбачає пом'якшення соціальної напруги та забезпечення узгодження різноманітних, а іноді i протилежних інтересів, соціальних груп та верств населення.

7) принцип соціальних гарантій передбачає досягнення мети щодо гарантування дотримання конституційного права громадян на належний життєвий рівень шляхом встановлення та забезпечення громадянам суспільства мінімум соціальних послуг. «Державні соціальні гарантії - встановленні законами мінімальні розміри оплати праці, доходів громадян, пенсійного забезпечення, соціальної допомоги, розміри інших видів соціальних виплат, встановленні законами та іншими нормативно-правовими актами, які забезпечують рівень життя не нижчий від прожиткового мінімуму [556]».

8) принцип соціальної солідарності має сприяти забезпеченню першочергових пріоритетних суспільних ініціатив щодо їх фінансування. «Серед найважливіших принципів соціальної політики слід визначити принцип солідарності (підтримки), який передбачає пріоритет суспільних ініціатив відносно відповідної діяльності державних органів та інститутів з фінансування соціальних заходів [535, с. 94]».

Як і більшість країн, так і Україна, у результати переходу на засада ринкової економіки, обрала дві основні моделі розвитку соціальної політики: 
континентальна (або бісмарківська) та англосаксонська (або модель Беверіджа).

Саме ці принципи соціальної політики формують у різних країнах або консервативну, або соціально-демократичну, або ліберальну політику.

Розглянемо основні характеристики цих моделей (рис. 10.2.5).

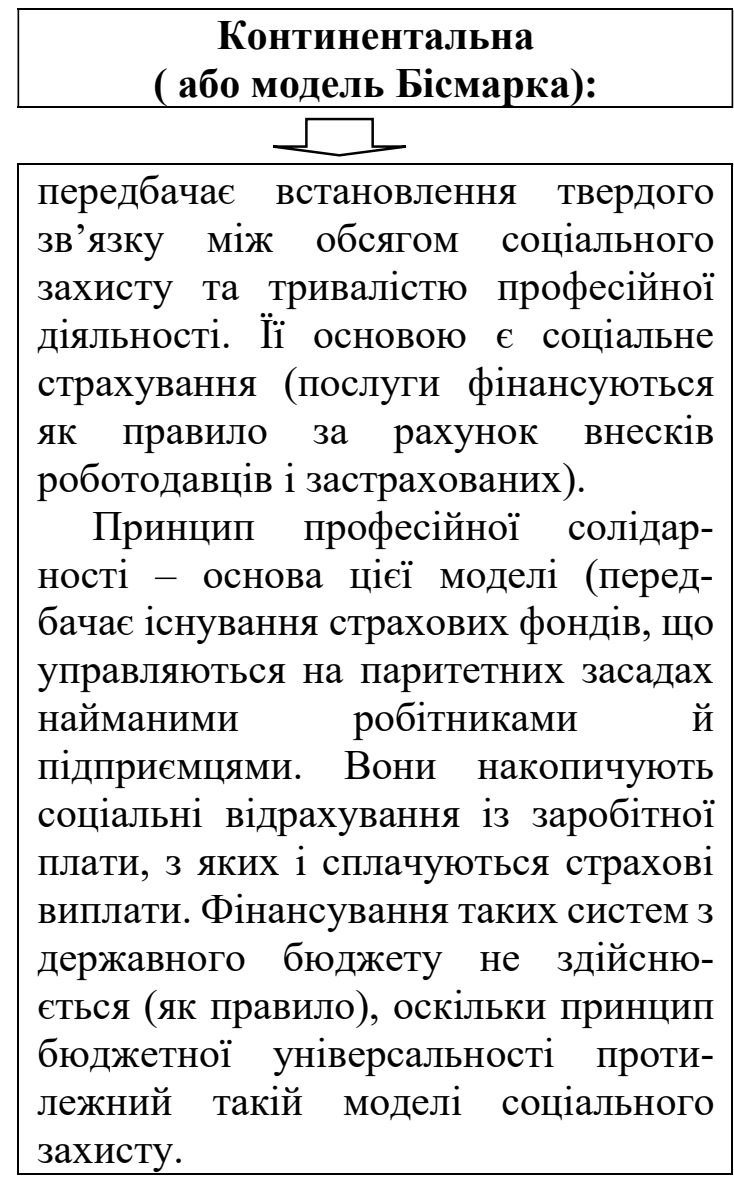

\begin{tabular}{|c|}
\hline $\mathbf{M}$ \\
$\mathbf{O}$ \\
Д \\
$\mathbf{E}$ \\
$\boldsymbol{J}$ \\
$\mathbf{b}$ \\
\\
$\mathbf{C}$ \\
$\mathbf{O}$ \\
$\mathbf{U}$ \\
$\mathbf{I}$ \\
$\mathbf{A}$ \\
$\mathbf{J}$ \\
$\mathbf{b}$ \\
$\mathbf{H}$ \\
$\mathbf{O}$ \\
$\mathbf{I}$ \\
$\mathbf{I}$ \\
$\mathbf{O}$ \\
$\boldsymbol{J}$ \\
$\mathbf{I}$ \\
$\mathbf{T}$ \\
$\mathbf{U}$ \\
\hline
\end{tabular}
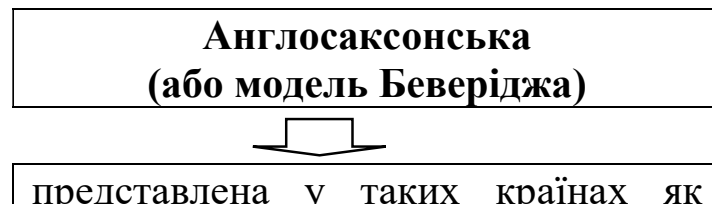

Великобританія та Ірландія.

Модель базується на таких принципах:

1) принцип загальності (універсальності) системи соціального захисту - поширення ii на всіх нужденних у матеріальній допомозі громадян;

2) принцип однаковості й уніфікації соціальних послуг і виплат виражається в однаковому розмірі пенсій, допомог і медичного обслуговування, а також умов їхнього надання;

3) принцип розподільної справедливості - наріжний у даній модель. Тут мова йде не про професійну солідарність як у моделі Бісмарка, а про солідарність на національному рівні.

\section{Рис. 10.2.5. Характеристики континентальної та англосаксонської}

\section{моделі соціальної політики}

Джерело: власне узагальнення.

А. Скуратівським, О. Палій, Е. Лібановою були наведені детальні характеристики основних моделей [538]. Варто зазначити, що ці дві моделі практично реалізуються у наступних 3-х моделях:

1. Консервативна модель. Її ідеологічну основу становить ідея виправдання соціальної диференціації в суспільстві. Майнова нерівність розцінюється як цілком природне і нормальне явище. Головна ж місія держави - через гнучку податкову політику здійснювати перерозподіл доходів, водночас надаючи компенсацію за допомогою трансфертів тим прошаркам, які їі потребують [538].

2. Ліберально-демократична модель. Усі фактори - законодавство, 
власність, ринкова економіка - в державі $€$ механізмами координації індивідуальних інтересів. В ідеалі держава бере на себе функцію стимулятора індивідуальної активності, заохочуючи своїх громадян до пошуку роботи, соціального захисту, підприємницької ініціативи. Правова база ліберальної моделі соціальної політики сфокусована на громадянських правах, зокрема на рівноправності громадян незалежно від расових, етнічних, статевих та інших ознак. Свою головну місію держава вбачає в охороні прав людини, тоді як охорона соціальних прав значною мірою перекладається на громадські організації й саму особистість. Пріоритетними у таких суспільствах $\epsilon$ громадянські, політичні, а лише потім - соціальні права [538].

3. Соціал-демократична модель акцентує увагу на запобіганні різкій диференціації найвищого та найнижчого рівня доходів. Серед управлінських важелів вагомими є самоврядні структури. Соціальні гарантії грунтуються як на державній, так і на недержавній підтримці. У функціональному відношенні державна політика спрямована на забезпечення всіх громадян роботою. Зайнятість утворює стабільну податкову базу. Рівень оподаткування загалом значно вищий, ніж, скажімо, в ліберальній моделі. Це й дає змогу державі здійснювати перерозподіл бюджету, забезпечуючи громадян соціальною допомогою. Правові пріоритети даної моделі зосереджені на соціальних правах як на головній меті соціальної політики [538]».

П. Спікер [548] дійшов висновку про те, що особливу значимість має формування та використання різноманітних й взаємопов'язаних механізмів соціальної політики державою. Механізм соціальної політики має чітке обгрунтування та направленість - гарантувати відповідний рівень життя населенню та дотримання соціальної справедливості щодо розподілу національного доходу через затвердження мінімального гарантованого рівня оплати плати, що повинен забезпечити:

- $\quad$ набір товарів основної групи та послуги для фізіологічних i соціальних потреб; 
- визнання власних доходів джерелом основного благополуччя;

- забезпечення безпеки та рівноваги в екологічному напрямку;

- збереження генофонду нації;

- формуванню системи пільг i компенсацій, що $є$ дієвими та обгрунтованими, а також збільшення розмірів допомоги тих, хто її потребує;

- забезпечення доступної та безоплатної повної загальної середньої освіти, а також професійно-технічної освіти;

- розвиток соціальної інфраструктури за рахунок держави;

- проведення активних заходів політики щодо набуття громадянами нових спеціальностей, підвищенню їх кваліфікації та перенавчанню.

Механізм здійснення соціальної політики держави представлено на рисунку 10.2.6.

\begin{tabular}{|c|c|c|c|c|}
\hline \multicolumn{5}{|c|}{ Механізми соціальної політики } \\
\hline 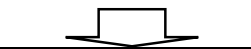 & $\sqrt{2}$ & $\square$ & 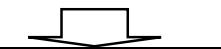 & 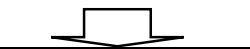 \\
\hline $\begin{array}{l}\text { Нормативно } \\
\text {-законодавче } \\
\text { регулювання }\end{array}$ & $\begin{array}{c}\text { Інструменти } \\
\text { та стимули } \\
\text { податкового } \\
\text { регулювання }\end{array}$ & $\begin{array}{c}\text { Фінансовий } \\
\text { механізм } \\
\text { регулювання }\end{array}$ & $\begin{array}{c}\text { Адміністра- } \\
\text { тивний } \\
\text { ресурсний }\end{array}$ & $\begin{array}{c}\text { Методи } \\
\text { політичного } \\
\text { регулювання }\end{array}$ \\
\hline
\end{tabular}

\section{Рис. 10.2.6. Механізми соціальної політики}

Джерело: власна розробка.

П. Спікер стверджував, що «до основних механізмів соціальної політики належать:

1. Законодавча та нормативна база, яка формується законодавчою владою у суспільстві та визначає загальні напрями соціальної політики;

2. Фінансовий механізм - визначається законодавчою та виконавчою владою та встановлює порядок формування та використання фінансових ресурсів, які необхідні для забезпечення заходів соціальної політики;

3. Податкові інструменти та стимули - використовуються 3 метою зацікавленості роботодавців у сприянні проведенню та реалізації соціальної політики, домогосподарств - у підвищенні рівня економічної самостійності, соціальної захищеності, які забезпечуються власними силами;

4. Адміністративний ресурс або адміністративні рішення, що використовує 
влада різних рівнів для підвищення рівня соціальної підтримки населення поряд із заходами, які передбачені законодавством країни;

5. Політичні методи - спрямовані на організацію та проведення мітингів, страйків, учасники яких висувають соціально-економічні вимоги, лобіювання конкретних рішень із соціальної політики [548, с. 28]».

Держава є головним учасником розробки і реалізації соціальної політики, тому активно використовує державні інструменти. На рисунку 10.2.7 наведені інструменти соціальної політики.

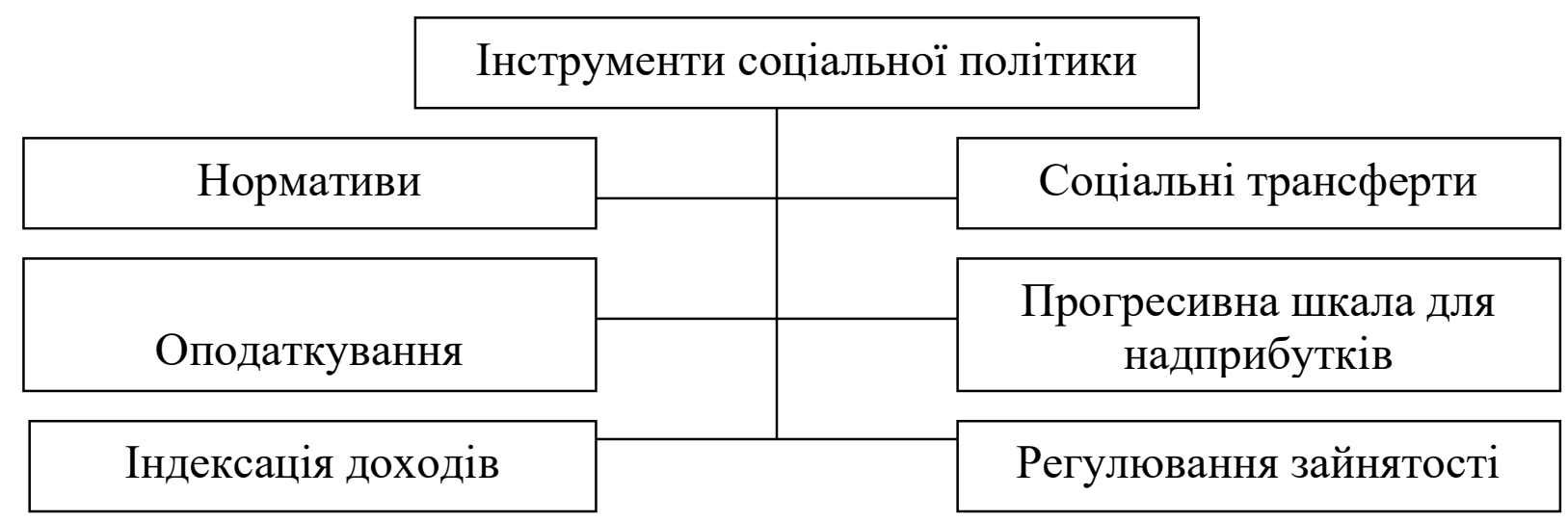

Рис. 10.2.7. Інструменти соціальної політики

Джерело: власна розробка.

О. Сергієнко дійшов висновку, що «серед цих інструментів найважливішу роль відіграють такі:

- нормативи, що визначають мінімальні стандарти споживання і діють як законодавчо встановлені й обов'язкові (величина прожиткового мінімуму, мінімальна зарплата і пенсія, гарантований мінімум послуг охорони здоров'я, житла тощо);

- соціальні трансферти, тобто різні засоби перерозподілу прибутків (регіональні субвенції, соціальні виплати і т. ін.);

- оподаткування, що стимулює створення нових робочих місць;

- уведення прогресивної шкали для надвисоких прибутків;

- індексація доходів - тобто збільшення їхнього номінального обсягу для запобігання зниження реального їхнього рівня. Індексація здійснюється шляхом регулювання номінальної зарплати, прибутків, процентних ставок. Індексація 
може йти за підвищенням цін або випереджати його.

- регулювання зайнятості - це здійснюваний державою за допомогою всіх юридичних засобів владний вплив на суспільні відносини в сфері зайнятості населення з метою їх упорядкування, закріплення, охорони та розвитку [536, с. $35] \gg$.

Отже, соціальна політика має розглядатися як правова політика, що орієнтована на людину, на ії добробут, безпеку та розвиток. Соціальна функція суб'єктів соціальної політики - державних та суспільних інститутів - не має обмежуватися лише турботою про соціально вразливі верстви населення, а бути спрямованою на все суспільство, тобто на усі суспільні потреби та вимоги людини. Оскільки соціальна політика в умовах сьогодення охоплює усі сфери суспільного життя, то вона набуває першочергового значення, а економічна та інші сфери діяльності уряду та державних органів повинні соціальні цілі ставити на перше місце, а не навпаки.

«Реалізація соціальної політики грунтується на основні забезпечення відповідного рівня життя населення і дотримання соціальної справедливості при розподілі національного доходу на основі встановлення мінімального рівня заробітної плати [536, с. 34]». Вона спроможна забезпечити суспільству підтримку економічної конкуренції завдяки соціальній злагоді, стабільності та правовим нормам, а також досягти економічного успіху через підвищення рівня продуктивності, творчу ініціативність та громадську довіру. Формується ефективна соціальна політика за рахунок такого:

- спрямовування на збереження та відтворення трудового потенціалу;

- запобігання високому рівню безробіття;

- запобігання занепаду соціальної сфери (об'єкти соціальної інфраструктури - охорона здоров'я, освіта, культура та інші).

Отже, лише поєднуючи соціальну політику з механізмом економічного зростання, можна посилити її роль у суспільстві.

Особливістю соціальної політики є наявність двох основних етапів:

1) стадії формування соціальної політики передбачає дотримання таких 
основних принципів: обгрунтованості - для забезпечення цілей, напрямів та задач необхідними ресурсами; реалістичності - орієнтація на пріоритетні соціальні проблеми. Перша стадія завершується прийняттям відповідного законодавчо-нормативного документу.

2) стадії реалізації соціальної політики передбачає дотримання таких основних принципів: конкретизації - відповідності соціально-економічних програм соціально-економічному плануванню; результативності - досягне-ння реалістичних результатів у визначений період. Для подолання соціальних проблем у суспільстві потрібна розробка та реалізація соціальної стратегічної програми, яка б була зрозумілою населенню з метою ії підтримки ним та здатної відновити довіру до влади. Основними причинами нереалізованості частини або повного варіанту соціально-економічних програм соціальної політики $є$ необгрунтованість і нереалістичність поставлених завдань.

Формування та реалізація соціальної політики має сприяти створенню середнього класу, забезпечення високих життєвих стандартів та рівня якості життя, а це можливо за умов досягнення довготривалої стратегічної мети соціальної політики. Схема формування та реалізації соціальної політики наступна (рис. 10.2.8):

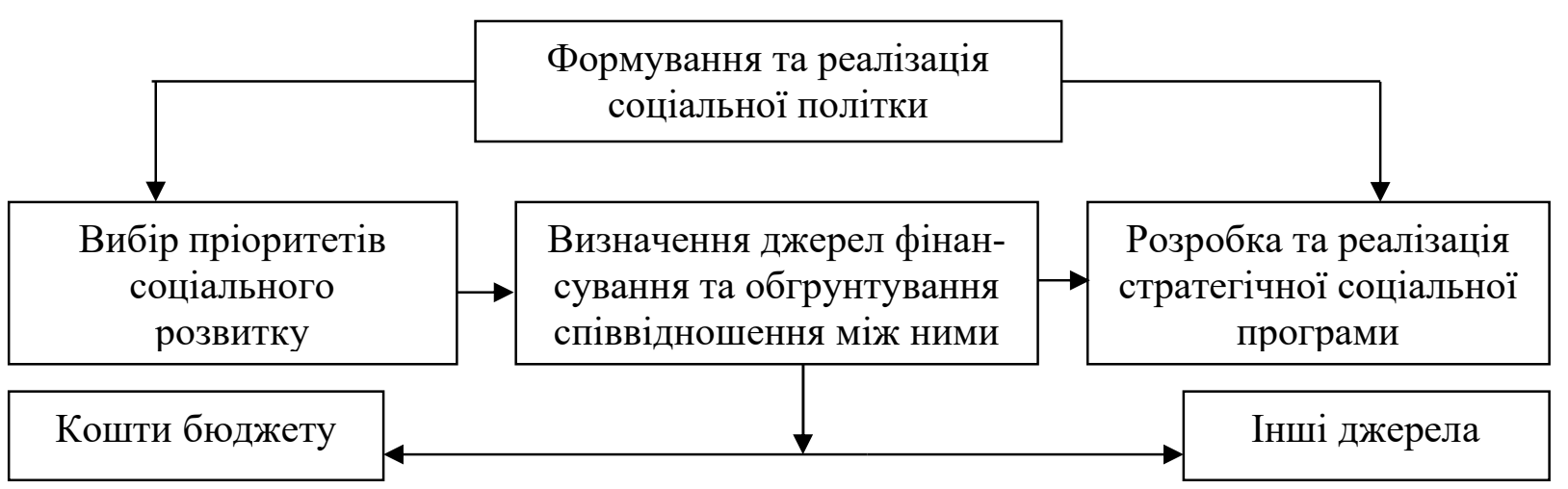

Рис. 10.2.8. Формування та реалізація соціальної політки

Джерело: [556], власне узагальнення.

Поняття «якість життя» значно ширше, ніж поняття «рівень життя», яке визначається, як правило, рівнем споживання благ і послуг матеріального характеру та величиною доходів населення. До якості життя належить таке: обсяг і характер зайнятості; умови праці; рівень освіти; забезпеченість житлом; 
система соціального забезпечення; екологічні умови життя.

Показники якості життя тісно пов'язані з параметрами якості самого населення, становищем генофонду, які включають фізіологічні та соціальноетичні характеристики. Тому, чітке визначення структурних елементів, що характеризують якість і рівень життя, - $є$ початковим пунктом вироблення обгрунтованої соціальної стратегії і політики, яка побудована на програмі подолання різкого зниження якості життя громадян.

До важливих стратегічних орієнтирів соціальної політики відноситься мотиваційне стимулювання активності (економічної) людини, створення передумов для iї ініціативності, розвитку енергій та здібностей, відкриття нових можливостей, що здатні забезпечити через працю гідний рівень життя. Така стратегічна направленість потребує значних зрушень у громадській свідомості і системі цінностей суспільства та подолання багаторічних стереотипів й звичок розраховувати не на свої сили, а на владу.

Не лише рівня та якості життя стосуються соціальні пріоритети. Сфери охорони здоров'я, культури, екології теж відносяться до них. Для їх визначення необхідним $\epsilon$ таке: визначення співвідношення між бюджетними i не бюджетними коштами; розмежування сфер застосування прямих і непрямих методів державного регулювання; розробки соціальних програм, що передбачають структурну переорієнтацію економіки на виробництво для збільшення споживання, розвитку житлового будівництва, охорони здоров'я, природоохоронних заходів.

Після вибору соціальних пріоритетів визначають джерела фінансування та співвідношення між ними. Джерелами фінансування можуть бути бюджетні та позабюджетні кошти: Бюджетні кошти включають кошти державного бюджету, регіональних та місцевих бюджетів, а також ресурси міжбюджетного перерозподілу, які підуть на видатки на соціальний захист і соціально-культурну інфраструктуру.

«Видатки на соціальний захист та соціальне забезпечення включають: виплату пенсій і допомоги; пільги ветеранам війни і праці; допомогу сім'ям 3 
дітьми; інші види соціальної допомоги; пенсії військовослужбовцям та особам начальницького і рядового складу; фінансування дитячих закладів-інтернатів, притулків для неповнолітніх, програм соціального захисту непов-нолітніх, будинків-інтернатів для пристарілих та інвалідів, інших закладів і заходів у галузі соціальної політики, молодіжних програм; кошти з бюджету, що передаються до Фонду соціального захисту інвалідів України [18]».

До державної соціальної допомоги громадянам належить щомісячна адресна готівкова грошова субсидії, що має відшкодувати витрати за плату й користування житлом та витрати на комунальні послуги - водо-, тепло-, газопостачання, водовідведення, електроенергія, вивезення побутового сміття та рідких нечистот, а також раз на рік субсидія на придбання скрапленого газу, твердого чи рідкого пічного побутового палива.

Видатки на соціальну сферу включають виділення коштів на освіту (загальноосвітні школи, школи-інтернати, дошкільні заклади, професійнотехнічні училища, заклади післядипломної освіти); охорону здоров'я (медичні установи, санітарно-епідеміологічна служба); культуру (театри, бібліотеки, музеї, заповідники); ЗМІ - телебачення і радіомовлення, книговидання, преса,та ін.; фізичної культури і спорту.

До позабюджетних коштів належать кошти державних соціальнострахових фондів, регіональних позабюджетних фондів, територіальні займи, кошти недержавних соціальних фондів, кредитні ресурси і грошовий потенціал некомерційних неурядових установ. Ці кошти формуються за рахунок страхових платежів, обов'язкових страхових внесків працюючих громадян, інших джерел (асигнування і дотації з держбюджету). До державних соціальних страхових фондів відносять: Фонд зайнятості, Пенсійний фонд, Фонд соціального страхування, Фонд страхування на випадок травматизму i професійної захворюваності.

Отже, лише після обгрунтованого визначення джерел фінансування соціальної політики та співвідношення між ними, можна розпочати роботу щодо розробки та реалізації соціальної програми. 
Реалізовується соціальна політика вона за напрямами, представленими на рисунку 10.2.9 та у таблиці 10.2.1.

Напрямами формування та реалізації соціальної політики

\begin{tabular}{|c|c|}
\hline $\begin{array}{c}\text { Забезпечення цільового характеру } \\
\text { пільг соціального спрямування }\end{array}$ & Впровадження пенсійної реформи \\
\hline $\begin{array}{l}\text { Посилення впливу держави на розподіл } \\
\text { доходів через фіскальні механізми }\end{array}$ & $\begin{array}{c}\text { Стимулювання розвитку } \\
\text { національного виробництва }\end{array}$ \\
\hline $\begin{array}{c}\text { Активізація державної політики на } \\
\text { ринку праці }\end{array}$ & $\begin{array}{c}\text { Заохочення й розвиток соціальної } \\
\text { відповідальності бізнесу }\end{array}$ \\
\hline $\begin{array}{c}\text { Заохочення підприємств до дій шодо } \\
\text { підвишення продуктивності праці та } \\
\text { збільшення доходів працюючих }\end{array}$ & $\begin{array}{c}\text { Підвишення ефективності } \\
\text { використання бюджетних впдатків на } \\
\text { соціальну сферу }\end{array}$ \\
\hline
\end{tabular}

Рис. 10.2.9. Напрямами формування та реалізації соціальної політики Джерело: [561, с. 89]

Таблиця 10.2.1

\section{Напрями формування та реалізації соціальної політики}

\begin{tabular}{|l|l|}
\hline Напрямам & Характеристика напряму \\
\hline $\begin{array}{l}\text { Забезпечення } \\
\text { цільового } \\
\text { характеру пільг } \\
\text { соціального } \\
\text { спрямування: }\end{array}$ & $\begin{array}{l}\text { виключення користуванням пільг особами, які не мають потреби в їх } \\
\text { отриманні через монетизацію частини пільг; нормування пільг 3 } \\
\text { реєстру пільговиків, єдиного електронного обліку прав на отримання } \\
\text { пільг, дохідного цензу. }\end{array}$ \\
\hline $\begin{array}{l}\text { Впровадження } \\
\text { пенсійної } \\
\text { реформи: }\end{array}$ & $\begin{array}{l}\text { формування механізмів інвестиційного використання коштів } \\
\text { пенсійних фондів, державний нагляд-контроль та гарантуванням } \\
\text { надійності їхніх вкладень. }\end{array}$ \\
\hline $\begin{array}{l}\text { Посилення } \\
\text { впливу держави } \\
\text { на розподіл } \\
\text { доходів через } \\
\text { фіскальні } \\
\text { механізми: }\end{array}$ & $\begin{array}{l}\text { вилучення та перерозподіл частини отримуваних в суспільстві } \\
\text { завдяки продуктивності, а через недосконалість ринків. Це можливе за } \\
\text { рахунок запровадження: прогресивної ставки прибуткового } \\
\text { оподаткування громадян; оподаткування нерухомості; впорядкування } \\
\text { розрахунку величини та сплати рентних платежів за використання } \\
\text { надр, аграрних, природно-кліматичних, рекреаційних ресурсів. }\end{array}$ \\
\hline
\end{tabular}




\begin{tabular}{|c|c|}
\hline $\begin{array}{l}\text { Стимулювання } \\
\text { розвитку } \\
\text { національного } \\
\text { виробництва: }\end{array}$ & $\begin{array}{l}\text { спрощення умов для довгострокового кредитування інвестиційних } \\
\text { проектів; розбудова інфраструктури внутрішнього ринку; підтримка } \\
\text { вітчизняного виробника щодо виробництва того, що потребує } \\
\text { споживач. }\end{array}$ \\
\hline $\begin{array}{l}\text { Активізація } \\
\text { державної } \\
\text { політики на } \\
\text { ринку праці: }\end{array}$ & $\begin{array}{l}\text { забезпечення державного замовлення на підготовку фахівців; } \\
\text { запровадження механізмів перепідготовки працівників; підвищення } \\
\text { територіальної мобільності працівників; розширення мережі } \\
\text { соціальних робіт для вивільнених працівників. }\end{array}$ \\
\hline $\begin{array}{l}\text { Заохочення й } \\
\text { розвиток } \\
\text { соціальної } \\
\text { відповідальності } \\
\text { бізнесу: }\end{array}$ & $\begin{array}{l}\text { запровадження фіскальних засобів заохочення соціальної } \\
\text { відповідальності бізнесу та міжнародних соціальних стандартів } \\
\text { ведення бізнесу; пропагування цінностей та стандартів соціально } \\
\text { відповідального бізнесу; державна підтримка національних і } \\
\text { міжнародних ініціатив щодо соціальної відповідальності. }\end{array}$ \\
\hline $\begin{array}{l}\text { Підвищення } \\
\text { ефективності } \\
\text { використання } \\
\text { бюджетних } \\
\text { видатків на } \\
\text { соціальну сферу: }\end{array}$ & $\begin{array}{l}\text { передбачає модернізацію управління установами соціальної сфери; } \\
\text { запровадження страхових засад в наданні соціальних послуг; } \\
\text { раціоналізацію фінансових установ соціальної сфери; збільшення } \\
\text { інвестиційної складової соціальних видатків для уникнення } \\
\text { непоправних втрат соціальної інфраструктури; диверсифікацію } \\
\text { надавачів соціальних послуг. }\end{array}$ \\
\hline $\begin{array}{l}\text { Заохочення } \\
\text { підприємств до } \\
\text { дій щодо } \\
\text { підвищення } \\
\text { продуктивності } \\
\text { праці та } \\
\text { збільшення } \\
\text { доходів } \\
\text { працюючих }\end{array}$ & $\begin{array}{l}\text { формуванням нового мислення керівників і стилю управління щодо } \\
\text { підвищення ефективності використання усіх видів ресурсів, які задіяні } \\
\text { у виробничому процесі, підвищення якості продукції і зростання } \\
\text { обсягу виробництва на одиницю ресурсів; забезпечення динамічної } \\
\text { рівноваги між результатами праці і винагородою, між потребами } \\
\text { різних груп носіїв інтересів на підприємстві використовуються } \\
\text { принципи системи мотивації праці персоналу підприємства, що } \\
\text { полягають в економічності, соціальному захисті та стабільності, } \\
\text { корпоративності. }\end{array}$ \\
\hline
\end{tabular}

Джерело: власне узагальнення.

Як правило, соціальна політика держави спрямована на соціально вразливі верстви населення. Соціальну роботу здійснюють державні структури, різні громадські організації та церковні громади. Їх діяльність направлені на соціально вразливі верстви населення. До них відносяться:

1) індивіди або соціальні групи, що мають ймовірність зазнати негативних впливів (соціальних, екологічних або дістати хвороби). Серед них виділяють такі категорії:

1.1) бездомні;

1.2) родини з проблемами дитячої занедбаності, сексуальних зловживань 
у родині;

1.3) подружні пари, які мають серйозні подружні конфлікти;

1.4) родини, де дитину виховує лише один із батьків та де є конфлікти;

2) ВІЛ-інфіковані люди та їхні родини;

3) Особи з низькими доходами через відсутність постійної роботи, відсутністю годувальника, фізичними вадами, низький рівень професійної підготовки тощо;

4) особи, які порушили закон, були визнаними винними та несуть покарання;

5) вагітні дівчата-підлітки;

6) сексуальні меншини, які мають особисті або сімейні проблеми;

7) особи, які мають тілесні або психічні захворювання, або мають інвалідність;

8) залежні від алкоголю, наркотиків та їхні родини;

9) іммігранти та національні меншини, жертви расизму та дискримінації;

10) особи із затримками розвитку (інваліди розвитку) та їхні родини;

11) літні люди, які не можуть адекватно функціонувати;

12) мігранти та біженці, які мають недостатні необхідні ресурси;

13) проблемні діти та їхні родини;

14) особи, що перебувають постійному стресі або перенесли травмуючі події (наприклад, вихід на пенсію чи смерть близької людини), а також бездомні діти.

До категорій громадян, що не можуть конкурувати на ринку праці, належать:

1) молодь, яка закінчила чи припинила навчатися у середніх загальноосвітніх школах, професійно-технічних закладах, а також звільненні зі строкової військової;

2) діти-сироти, діти, батьки яких про них не піклуються, а також особи, 
що не досягли 18 років, але змушені працювати;

3) жінки, які мають дітей віком до шести років;

4) матері-одиначки, що мають малолітніх дітей або дітей інвалідів;

5) багатодітні сім'ї;

6) неповні сім’ї та сім'ї з дітьми;

7) інваліди;

8) особи передпенсійного віку тощо.

Соціальна політика не повинна визначатися лише підтримкою малозабезпечених прошарків населення, але має передбачати і захист осіб, що беруть участь у суспільному виробництві - людей, що працюють за наймом, тобто економічно активне населення. Соціальний захист економічно активного населення має формуватися як багаторівнева та організована система заходів, які спрямовані щодо мінімізації соціальної напруги, конфліктів і суперечностей соціального характеру в суспільстві, i, як наслідок, на забезпечення ефективного розвитку економіки. Ефективний захист та якісна підтримка населення соціального характеру $є$ основою економічного зростання. Соціальний захист економічно активного населення має передбачати такі дії держави, які спрямовані на гарантії у сфері зайнятості населення через регламенти праці у формі законів: тривалість робочого тижня, охорони праці, тривалості та порядку надання відпусток; оплату праці працівників через установлення мінімальних ставок заробітної плати; гарантування прав працівників при прийомі на роботу $\mathrm{i}$ звільненні. Ця сторона соціальної політики теж обумовлена рівнем економічного розвитку країни, співвідношенням політичних сил i рівнем суспільної самосвідомості.

Соціальний захист забезпечують і підприємства (або підприємці), і самі наймані робітники через систему соціального страхування - пенсійного, медичного, від безробіття, від нещасливих випадків на виробництві. Крім того, важливою ланкою соціального захисту населення є програми працевлаштування і перекваліфікації.

Отже, наявність дієвої та ефективної системи соціального захисту - це 
головні ознаки рівня розвитку держави, ії відповідності вимогам сьогодення. Вищий рівень життя членів суспільства підтверджує розвиток самого суспільству. Прагнення України інтегруватися в Європейську співдружність країн не може мати перспектив без розробки комплексу правових, економічних, організаційних заходів як державних, так і недержавних організацій, що спроможні впливати та сприяти підтриманню соціальної стабільності в суспільстві, зростанню добробуту населення, забезпеченню належного рівня та якості життя населення.

Соціальною політикою прийнято вважати діяльність різних суб'єктів соціальної політики, яка спрямована на задоволення соціальних потреб як суспільства, так і окремої людини. При цьому, реалізація соціальних потреб, які мають забезпечити життєдіяльність та розвиток соціальної сфери, мають грунтуватися на безкомпромісному дотриманні основних громадянських прав та свобод, а також здійснюватися на засадах соціальної справедливості.

У Конституції України зазначено:

«Стаття 46. Громадяни мають право на соціальний захист, що включає право на забезпечення їх у разі повної, часткової або тимчасової втрати працездатності, втрати годувальника, безробіття з незалежних від них обставин, а також у старості та в інших випадках, передбачених законом.

Стаття 47. Кожен має право на житло. Громадянам, які потребують соціального захисту, житло надається державою та органами місцевого самоврядування безоплатно або за доступну для них плату відповідно до закону. ... Ніхто не може бути примусово позбавлений житла інакше як на підставі закону за рішенням суду.

Стаття 48. Кожен має право на достатній життєвий рівень для себе і своєї сім'ї, що включає достатнє харчування, одяг, житло.

Стаття 49. Кожен має право на охорону здоров'я, медичну допомогу та медичне страхування. Охорона здоров'я забезпечується державним фінансуванням відповідних соціально-економічних, медико-санітарних і 
оздоровчо-профілактичних програм. 1

Стаття 50. Кожен має право на безпечне для життя і здоров'я довкілля та на відшкодування завданої порушенням цього права шкоди. Кожному гарантується право вільного доступу до інформації про стан довкілля, про якість харчових продуктів і предметів побуту, а також право на ï поширення.

Стаття 53. Кожен має право на освіту. Повна загальна середня освіта $€$ обов'язковою. Громадяни мають право безоплатно здобути вищу освіту в державних і комунальних навчальних закладах на конкурсній основі.

Стаття 56. Кожен має право на відшкодування за рахунок держави чи органів місцевого самоврядування матеріальної та моральної шкоди, завданої незаконними рішеннями, діями чи бездіяльністю органів державної влади, органів місцевого самоврядування, їх посадових і службових осіб при здійсненні ними своїх повноважень [513]».

Державне управління соціальною політикою здійснюють Кабінет Міністрів України «Пункт 3 ст. 116 Конституції України фіксує функцію Кабінету Міністрів України по забезпеченню проведення фінансової, цінової, інвестиційної та податкової політики; політики у сферах праці й зайнятості населення, соціального захисту, освіти, науки і культури, охорони природи, екологічної безпеки і природокористування [513]». А також іiі здійснюють місцеві державні адміністрації, органи місцевого самоврядування та їх виконавчі й розпорядчі органи та інші.

Держава в реалізації соціальної політики виступає гарантом соціального й законодавчого порядку та способів їх забезпечення. Зокрема, Конституція України гарантує вище згадані права на свободу думки, працю, добровільного вибору професії та роду трудової діяльності, отримання якісної освіти та медичної допомоги. Держава не лише гарантує соціальні права, а й несе відповідальність перед населенням за їх забезпечення та формування гідного рівня життя.

Конституція України детально відображає гарантії, які стосуються соціального розвитку держави та рівня життя іï населення, можемо сюди 
віднести наступні закони: «Кодекс законів про працю України»; «Про допомогу сім'ям 3 дітьми»; «Про зайнятість населення»; «Про колективні договори та угоди»; «Про межу малозабезпеченості»; «Про основи соціальної захищеності інвалідів в Україні»; «Про основні засади соціального захисту ветеранів праці та інших громадян похилого віку в Україні»; «Про охорону праці»; «Про пенсійне забезпечення військовослужбовців та осіб начальницького та рядового складу»; «Про сприяння соціальному становленню і розвитку молоді в Україні»; «Про статус і соціальний захист громадян, які постраждали внаслідок Чорнобильської катастрофи» і т.д. [508].

Систему уповноважених структур, які наділені компетенцією щодо вирішення питань соціального захисту, утворює Міністерство праці та соціальної політики України. Його функції прописані у Положенні про Міністерство праці та соціальної політики України (затверджено Указом Президента України від 30 серпня 2000 р. №1035/2000 (з наступними змінами i доповненнями)). Діяльність Міністерства праці та соціальної політики України координується Кабінетом Міністрів України. Основними завданнями даної структури є:

- формування та забезпечення реалізації державної соціальної політики у сферах, що визначені;

- забезпечення «реалізації права громадян на соціальний захист» шляхом надання соціальної підтримки;

- участь у розробленні «Проектів Державної програми розвитку України», «Державного бюджету України»;

- проведення різних моніторингів у соціальній сфері (праці, зайнятості, соціального захисту, соціального страхування, пенсійного забезпечення, соціального обслуговування);

- нагляд 3 боку держави щодо загальнообов'язкового державного соціального страхування, а також за додержанням вимог законодавства 3 питань 
призначення і виплати пенсій;

- розроблення соціальних стандартів і нормативів на рівні державних.

Органи місцевого самоврядування мають теж повноваження у сфері соціального захисту населення, а саме:

- можуть за рахунок власних коштів та благодійних надходжень встановлювати додаткові гарантії до вже встановлених гарантій у відповідності до законодавства щодо соціального захисту населення;

- вирішувати питання із наданням допомог соціально незахищеним верствам населення, які були визначені на рівні законодавства України.

Місцеві Ради депутатів та їхні виконавчі органи крім власних повноважень здійснюють і низку повноважень у сфері соціального захисту, які їм делеговані державою (ст. 34 Закону України «Про місцеве самоврядування в Україні»).

До державних страхових фондів передусім належить Пенсійний фонд України (ПФУ). ПФУ не відноситься до центральних органів виконавчої влади. Бюджет ПФУ затверджує КМУ. Питаннями щодо призначення різних пенсій та соціальних допомог займаються спеціальні відділи системи органів праці та соціального захисту, а також інші установами, діяльність яких врегульована спеціальними нормативно-правовими актами.

У сфері недержавного соціального забезпечення $\epsilon$ також інституції, діяльність яких регулюється Законом України «Про недержавне пенсійне забезпечення», щодо недержавного пенсійного забезпечення та надання соціальних послуг - це: недержавні пенсійні фонди; страхові організації; банківські установи, які уклали договори страхування про відкриття депозитних рахунків пенсійного призначення; недержавні комерційні організації суб'єктів, які надають послуги недержавного пенсійного забезпечення; консультаційні та агентські послуги щодо недержавного пенсійного забезпечення.

Правове регулювання відносин у сфері соціального захисту має певну особливість, яка обумовлена юридичним способом здійснення урегулювання цієї сфери. Мова йде про спеціальний вид соціально-захисної функції держави через затвердження соціальних стандартів та стандартизацію в цілому, які спрямовані 
на реалізацію права людини вимагати встановлення на державному рівні певних мінімальних стандартів як систему базових показників для визначення рівня їх забезпеченості.

Система стандартизації соціальних прав включає:

1) створення каталогу соціальних прав;

2) визначення змісту (елементів) кожного права;

3) встановлення державних гарантій забезпечення прав;

4) встановлення системи контролю за забезпеченням соціальних прав.

Правові основи соціальної стандартизації прописані у Законі України «Про державні соціальні стандарти та державні соціальні гарантії» [34], де, у відповідно до ст. 27, наказом Міністерства праці та соціальної політики України від 17 червня 2002 р. №293 затверджено «Державний класифікатор соціальних стандартів та нормативів». Його розроблено з метою забезпечення соціальних прав та державних соціальних гарантій достатнього життєвого рівня для кожного громадянина у відповідності до Конституції України через законодавчого визначені державні соціальні стандарти і нормативи. «Державний класифікатор соціальних стандартів та нормативів» ураховує диференціацію за соціальнодемографічною ознакою, підходами до визначення нормативів, науковим обгрунтуванням визначення норм споживання, гласністю, громадським контролем.

Головним призначенням затвердження державних соціальних стандартів та нормативів є визначення такого:

- алгоритму реалізації соціальних прав та державних соціальних гарантій громадян (що гарантуються статтями Конституції України);

- пріоритетів державної соціальної політики щодо забезпечення потреб людини (матеріальні блага та послуги, а також фінансові ресурси для їх забезпечення);

- обгрунтованих розмірів потреби в коштах Державного бюджету України, місцевих бюджетів, соціальних фондів на захист і утримання соціальної 
сфери.

Соціальним стандартом у сфері доходів населення, що є державним базовим, є прожитковий мінімум, а його правове регулювання здійснюється відповідним Законом України «Про прожитковий мінімум». На основі соціальних стандартів на визначаються мінімальний розмір заробітної плати, мінімальний розмір пенсії за віком, неоподатковуваний мінімум доходів громадян, розмір державної соціальної допомоги та інших соціальні виплати, що $€$ розмірами основних соціальних гарантій.

Верховна Рада України в 1993 р. затвердила «Концепцію соціального захисту населення» [528]. В документі вказано, що джерелом підвищення добробуту населення є ефективна праця, трудова активність населення та підприємницька ініціатива громадян. Також зазначається, такі зміни $є$ можливими на основі сталого розвитку трудового потенціалу та його ефективного використання й застосування. Однак, не все ж не варто забувати про те, що зростання рівня життя людини прямо пропорційно їі власним доходам. Тому головну роль держава має звертати саме на умови праці людей та винагороду за пророблену роботу, причому саме в державних стандартах та доходних мінімумах криється шлях до забезпечення соціальних гарантій та соціального захисту. Згідно Концепції соціального забезпечення населення України, система соціального забезпечення громадян та населення повинна формуватись так, щоб не породжувати утриманство при розподілі соціальних благ. А також щоб заохочувати і стимулювати до праці, й створювати умови для реалізації цієї концепції.

Отже, головним завданням управління державною соціальною політикою має стати:

- зміна існуючих умов соціального забезпечення на краще;

- створення превентивних засобів щодо упередження негативних соціальних явищ;

- зростання рівня добробуту населення та недопущення зниження індексу людського розвитку (або потенціалу), який є індикатором демографічної 
та соціально-економічної сфери.

Отже, основою для реалізації та здійснення соціальної політики в Україні має стати взаємна та колективна відповідальність, а також державна гарантія щодо забезпечення взаємних соціальних обов'язків: держава-населення, населення-держава. Окрім цього, соціальна політика має постійно коригуватися у відповідності до стану економічного розвитку, постійно забезпечувати позитивні зміни мінімальних стандартів рівня життя населення та сприяти розвитку соціальних та економічних інституцій. Роль держави, як суб'єкта соціальної політики, є визначальною та головною, але має підкріплюватися діяльністю інших інститутів громадянського суспільства, які виконують частину функціональних обов'язків. Головна особливість ролі держави проявляється в відповідальності за безпеку та стабільність в середині суспільства та проведення соціальної політики, оскільки держава володіє широким спектром повноважень, що дозволяють їй виконувати головну формувальну та забезпечувальну роль.

Досліджуючи теоретичні основи формування та реалізації соціальної політики були зроблені такі висновки:

1. Державна соціальна політика являє собою багаторівневу та багатофункціональну систему, яка здатна забезпечити ефективний соціальноекономічний розвиток країни шляхом залучення людського капіталу й трудових ресурсів через реалізації їх потенціалу.

2. Структура соціальної політики держави складається з іï суб'єктів, об’єктів, принципів функціонування та механізмів впровадження (суб'єкти соціальної політики перебувають в постійній взаємодії і ця взаємодія направлена на створення необхідних умов для іiї об'єктів).

3. Інститути соціальної політики сприяють захисту громадян та зростанню людського потенціалу, і для яких перші мають пріоритетне значе-ння через найбільшу близькість до вирішення потреб конкретних людей.

4. Ключовим механізмом реалізації соціальної політики є соціальне страхування, соціальні гарантії та послуг з боку держави та громадських організацій. Але даний механізм має ряд прогалин через його недосконалість та 
неузгодженість, що ускладнює соціальний захист населення.

5. Впровадження та реалізацію соціальної політики здійснює Міністерство соціальної політики, яке є уповноваженим центральним органом виконавчої влади із забезпечення рівних прав та можливостей щодо надання допомоги.

6. На шляху до вдосконалення системи соціального захисту населення одним 3 важливіших моментів має стати розширення його конкретизації та направленості. Але варто зазначити, що тільки на рівнях областей , районів, підприємств можна достовірно визначити на скільки людина, що звернулася за допомогою, насправді іï потребує.

Розділ 2. Оцінка соціальної політики як елемента інтегрального механізму покращення якості життя населення України. Сьогодні Україна знаходиться у відверто складних трансформаційних умовах - військові події на Сході країни, погіршення економічної ситуації, зростання соціальної напруги. Все це зменшує шанси на реалізацію соціальної політики та економічний розвиток. Досягнення економічного та демографічного розвитку $є$ неможливим без потужної та структурно розвиненої соціально-економічної бази.

«Якість життя» відноситься до комплексного поняття, що враховує має враховувати різні аспекти людського життя ,а з точки зору оцінювання - це $\epsilon$ багатовимірна величина. Для забезпечення адекватної оцінки, іï будують шляхом використання національної матриці індикаторів, які максимально адаптовані до державної статистики. Національна матриця індикаторів може включати показники, які даний час не розраховуються, але можуть бути розрахованими. Крім того, вона повинна забезпечити можливість міжнародних порівнянь. Кожен індикатор розглядається $з$ двох боків:

- за джерелом отримання (об'єктивний чи суб'єктивний);

- як характеристика певної середовища життєдіяльності.

Для забезпечення рівня якості життя населення відповідного рівня зусилля спрямовуються $з$ двох боків:

- діяльність держави щодо забезпечення належного рівня якості життя 
населення;

- безпосередні зусилля громадян.

Такий поділ є умовним, оскільки, з одного боку - діяльність держави має обмежені можливості через стан економіки та населення, яке має особливості у його характеристиці: статевовіковій структурі, поведінці на ринку праці тощо; а 3 іншого боку - активність населення суспільно-економічного характеру грунтується на тих «правилах гри», які пропонує держава.

Отже, якість життя забезпечується як державою так i населенням. Ефективність зусиль держави $є$ меншою, ніж самого населення, тобто, економічне зростання та збільшення фінансування певних програм, які мають ефективність не завжди, призводить до певного зростання якості життя, а от зростання доходності громадян - завжди перетворюється у підвищення якості життя. Разом з тим, кожна людина як особистість має свою уяву про якість життя та можливості щодо іiі забезпечення у конкретних умовах існування. Тому, при розробці національної матриці індикаторів якості життя виокремили три блоки показників:

- блок 1: кількісно описує зовнішне середовище, характеризує досягнутий стан, в якому відбувається життя людини, і здійснює оцінку якості життя;

- блок 2: забезпечує оцінку поточного стану якості життя, який має бути сформований як результат спільного впливу держави та населення;

- блок 3: показники, що відбивають суб’єктивну оцінку стану якості життя самим населенням, які характеризують якість життя 3 точки зору індивідуума, його сприйняття доступності різних ресурсів та можливості щодо їх використання.

Лише при оптимальній збалансованості компонентів усіх трьох вказаних блоків можна досягти високого рівня якості життя. Доступність чинників якості життя може забезпечити високу статусність та високу самооцінку досягнутого статусу, а можливі дисбаланси за трьома компонентами вказують на проблеми щодо досягнення високої якості життя. Об'єктивні та суб'єктивні оцінки 
об’єднуються і можуть дати чотири варіанти розвитку подій (табл. 10.2.2):

Таблиця 10.2.2

Матриця стану якості життя населення

\begin{tabular}{|c|c|c|}
\hline Суб’єктивна & \multicolumn{2}{|c|}{ Об’єктивна } \\
\hline оцінка & добре & погано \\
\hline добре & БЛАГОПОЛУЧЧЯ. & $\begin{array}{c}\text { АДАПТАЦІЯ. } \\
\text { («щасливі бідні люди») }\end{array}$ \\
\hline \multirow{2}{\text{погано}}{} & $\begin{array}{c}\text { ДИСОНАНС. } \\
\text { Невідповідність очікуваної і } \\
\text { отриманої якості життя }\end{array}$ & ВІДТОРГНЕННЯ. \\
\hline
\end{tabular}

Джерело: [564].

Залежно від сфер людської життєдіяльності диференціюються характеристики середовища життя. Виділяють природне, соціальне, економічне та суспільно-політичне середовище, а у відповідності до специфіки впливу цих середовищ на якість життя, розрізняють чотири підсистеми якості життя: якість громадського, трудового, сімейного та особистого життя (рис. 10.2.10).

\begin{tabular}{|l|c|c|c|}
\hline \multicolumn{5}{|c|}{ СЕРЕДОВИЩЕ } \\
\hline економічне & природне & суспільно-політичне & соціальне \\
\hline \multicolumn{4}{|c|}{ ЯКІСТЬ ЖИТТЯ } \\
\hline громадського & трудового & сімейного & особистого \\
\hline \multicolumn{2}{|c|}{ ПІДСИСТЕМИ } \\
\hline
\end{tabular}

Рис. 10.2.10. Середовище та підсистеми якості життя населення

Джерело: розроблено автором на основі узагальнення.

Отже, при формуванні національної матриці індикаторів якості життя, виділяють блоки стану, поточної ситуації, суб'єктивної оцінки, а також чотири природне, соціальне, економічне, суспільно-політичне середовища (три останні середовища мають свої субсередовища). Блоки, середовища та їх структурні елементи наведені дозволяють мати чітку уяву про те, чому конкретні особливості життєдіяльності населення, умови проживання та стан населення $є$ саме такими, а не іншими. Оцінка якості життя має грунтуватися на існуючих сучасних концепціях та теоріях, які дозволяють отримати чіткі відповіді та 
пояснити вплив процесу соціально-економічного розвитку та результати.

Таким чином, до основних принципів, які мають застосовуватися до оцінки якості життя населення $\epsilon$ : системність оцінки; комплексність оцінки; динамічність оцінки; підбір універсальних показників оцінки; урахування особливостей минулого періоду; застосування гендерно-вікового підходу для того, щоб краще осмислили специфіку соціального розвитку. Принципи вимірювання якості життя, передбачають, що вимірювання повинно складатися 3 інтегрального індексу та набору субіндексів, які утворюють відповідно до структури системи показників. Тобто, загальна оцінка є інтеграційною від часткових оцінок. Звідси виникає питання - що таке елементарний індекс, який би, по-перше, розраховувався на основі визнаного набору показників, а, подруге, слугував складовою для розрахунку субіндексів та інтегрального індексу. «Розрахунок індексу структурного елементу матриці має свою послідовність передбачає три етапи: нормування показників; визначення ваг показників; розрахунок індексу [564]».

«Індекс структурного елементу матриці розраховується за формулою:

$$
\mathrm{I}=\Sigma\left(\mathrm{Z}_{\mathrm{i}} \times \mathrm{W}_{\mathrm{i}}\right)
$$

де, $\mathrm{Z}_{\mathrm{i}}$ - нормоване значення i-го показника; $\mathrm{W}_{\mathrm{i}}$ - вага $\mathrm{i}-$-го показника [564]».

В Україні сформована своя національна матриця індикаторів для визначення якості життя (табл. 10.2.3). 
Таблиця 10.2.3

Національна матриця індикаторів якості життя населення в Україні

\begin{tabular}{|c|c|c|c|}
\hline \multicolumn{4}{|c|}{ ЯКІСТЬ ЖИТТЯ } \\
\hline \multirow{3}{*}{$\begin{array}{c}\text { Середовище } \\
\text { (субсередовище) }\end{array}$} & \multicolumn{3}{|c|}{ Блоки } \\
\hline & \multicolumn{2}{|c|}{ Об’єктивна оцінка } & Суб’єктивна \\
\hline & стан & поточна ситуація & оцінка \\
\hline \multicolumn{4}{|c|}{ Природне середовище } \\
\hline Екологія & Природне середовище & Екологічна ситуація & $\begin{array}{c}\text { Оцінка екологічної } \\
\text { ситуації }\end{array}$ \\
\hline \multicolumn{4}{|c|}{ Соціальне середовище } \\
\hline Здоров'я & $\begin{array}{l}\text { Система охорони } \\
\text { здоров'я }\end{array}$ & Здоров’я населення & $\begin{array}{c}\text { Оцінка системи охорони } \\
\text { здоров'я та власного } \\
\text { здоров’я }\end{array}$ \\
\hline Освіта & Система освіти & Освіта населення & $\begin{array}{c}\text { Оцінка системи освіти та } \\
\text { власної освіти }\end{array}$ \\
\hline Безпека & $\begin{array}{l}\text { Криміногенне } \\
\text { середовище }\end{array}$ & $\begin{array}{l}\text { Криміногенна } \\
\text { ситуація }\end{array}$ & $\begin{array}{c}\text { Оцінка особистої } \\
\text { безпеки }\end{array}$ \\
\hline $\begin{array}{l}\text { Культура, } \\
\text { мистецтво, } \\
\text { відпочинок }\end{array}$ & $\begin{array}{c}\text { Сфера культури, } \\
\text { мистецтва, туризму }\end{array}$ & $\begin{array}{l}\text { Активність населення } \\
\text { у сфері культури, } \\
\text { мистецтва, туризму }\end{array}$ & $\begin{array}{c}\text { Ставлення до культури, } \\
\text { мистецтва, туризму }\end{array}$ \\
\hline Житло & Ринок житла & Житлові умови & $\begin{array}{c}\text { Оцінка благоустрою та } \\
\text { умов проживання }\end{array}$ \\
\hline Транспорт & $\begin{array}{c}\text { Транспортна } \\
\text { інфраструктура }\end{array}$ & Безпека на транспорті & $\begin{array}{c}\text { Оцінка роботи } \\
\text { транспорту }\end{array}$ \\
\hline \multicolumn{4}{|c|}{ Економічне середовище } \\
\hline Економіка & Стан економіки & Добробут & $\begin{array}{c}\text { Оцінка матеріального } \\
\text { становища }\end{array}$ \\
\hline Зайнятість & Ринок праці & $\begin{array}{c}\text { Зайнятість та умови } \\
\text { праці }\end{array}$ & $\begin{array}{c}\text { Оцінка ситуації } 3 \\
\text { зайнятості }\end{array}$ \\
\hline \multicolumn{4}{|c|}{ Суспільно-політичне середовище } \\
\hline $\begin{array}{c}\text { Громадянська } \\
\text { активність }\end{array}$ & $\begin{array}{l}\text { Розвиток громадян- } \\
\text { ського суспільства }\end{array}$ & $\begin{array}{c}\text { Суспільно-політична } \\
\text { ситуація }\end{array}$ & $\begin{array}{c}\text { Оцінка суспільно- } \\
\text { політичної ситуації }\end{array}$ \\
\hline $\begin{array}{c}\text { Суспільне } \\
\text { середовище }\end{array}$ & $\begin{array}{c}\text { Стан суспільного } \\
\text { середовища }\end{array}$ & Соціальне уособлення & Соціальне самопочуття \\
\hline
\end{tabular}

Джерело: [564].

Подальша робота з інтегральним індексом і субіндексами зводиться до, розрахунку або сумарного, або середнього показника. Перші дають змогу визначити внесок кожного індексу в узагальнюючий індекс, а другі - тоді, коли кількість складових сукупностей при порівнянні відрізняються.

У дослідженнях за різними програмами використовують 9 факторів для оцінки якості життя для визначення оцінки країни. Опис показників, які враховувалися при складанні рейтингу, представлено у таблиці 10.2.4. 
Таблиця 10.2.4

Основні індикатори оцінки якості життя

\begin{tabular}{|c|c|c|c|}
\hline $\begin{array}{l}\text { № } \\
\text { П/II }\end{array}$ & Індикатор & Показник індикатора & Джерело \\
\hline 1. & Здоров’я: & очікувана тривалість життя (в роках) & US Census Bureau \\
\hline 2. & Сімейне життя: & $\begin{array}{l}\text { рівень розлучень на } 1 \text { тисячу осіб. } \\
\text { Ставиться оцінка від } 1 \text {, що означає мало } \\
\text { розлучень, до } 5 \text { - багато розлучень. }\end{array}$ & $\mathrm{OOH}$; Euromonitor \\
\hline 3. & Громадське життя: & $\begin{array}{l}\text { значення на рівні 1, якщо високий рівень } \\
\text { відвідування церков або кількість } \\
\text { профспілкового членства. }\end{array}$ & World Values Survey \\
\hline 4. & $\begin{array}{l}\text { Матеріальний } \\
\text { добробут: }\end{array}$ & $\begin{array}{l}\text { ВВП на душу населення, Паритет } \\
\text { купівельної спроможності. }\end{array}$ & $\begin{array}{l}\text { Economist } \\
\text { Intelligence Unit }\end{array}$ \\
\hline 5. & $\begin{array}{l}\text { Політична стабіль- } \\
\text { ність та безпека: }\end{array}$ & $\begin{array}{l}\text { Рейтинги політичної стабільності та } \\
\text { безпеки. }\end{array}$ & $\begin{array}{l}\text { Economist } \\
\text { Intelligence Unit }\end{array}$ \\
\hline 6. & $\begin{array}{l}\text { Клімат } \\
\text { географія: }\end{array}$ & $\begin{array}{l}\text { Широта, що розділяе холодних та } \\
\text { жарких клімати. }\end{array}$ & CIA World Factbook \\
\hline 7. & Гарантія роботи: & Рівень безробіття (у \%). & $\begin{array}{l}\text { Economist } \\
\text { Intelligence Unit }\end{array}$ \\
\hline 8. & $\begin{array}{l}\text { Політична } \\
\text { свобода: }\end{array}$ & $\begin{array}{l}\text { Значення від 1, якщо повністю вільна, } \\
\text { до } 7 \text { - невільна. }\end{array}$ & Freedom House \\
\hline 9. & Статева рівність: & $\begin{array}{l}\text { визначається діленням } \quad \text { середньої } \\
\text { заробітної плати чоловіків на заробітну } \\
\text { плату жінок. }\end{array}$ & $\begin{array}{l}\text { UNDP Human } \\
\text { Development Report }\end{array}$ \\
\hline
\end{tabular}

Джерело: власна розробка.

Наведемо основні результати таких досліджень. «ООН визнало наш рівень розвитку як високий. На основі отриманих показників країнам присвоюються певні індекси щодо людського розвитку, за якими їх поділяють на 4 групи: $з$ дуже високим (увійшли такі як Чехія, Польща, Словаччина, Угорщина, Румунія та інші); високий (увійшли такі як Україна, Болгарія, Грузія, Туреччина та інші); середній (Молдова та інші); низьким [563]».

Науковці інституту демографії та соціальних досліджень імені М. В. Птухи НАН України, стверджували, що «впродовж останньої чверті сторіччя Україна зіткнулася 3 абсолютно новими для себе викликами, зумовленими набуттям незалежності й розривом традиційних зв'язків у межах колишнього СРСР та формуванням нових міжнародних контактів. Ми долучи-лися до нового глобалізованого світу, що спричинило глибоку економічну кризу перехідного періоду. I відійшовши від задекларованої за радянських часів рівності для всіх, 
виявили поміж себе кричущу нерівність Таку глибоку, що, нині вона може навіть спричинити розподіл суспільства на касти [563]».

За звітними даними середня тривалість життя в Україні обох статей нині становить у середньому 71,1 року. Це, на жаль, нижче, ніж середній показник у світі - 71,7. І лише на 1,3 року більше, ніж було у 1990-му. Для порівняння - у країнах з дуже високим рівнем розвитку: у Чехії - 78,8, у Польщі - 77,6, в Угорщині - 75,3. У країнах нашої групи: в Туреччині - 75,5, в Грузії - 75 років, в Болгарії - 74,3. І навіть у Молдові, яка належить до країн із середнім розвитком, - 71,7. I це попри те, що в середині 1990-х середня тривалість життя в Україні та Польщі була однаковою.

Середня тривалість життя жінок в Україні - 76 років, чоловіків - 66,2 року. Трохи менша вона лише в жінок у Молдові - 75,9 років, а чоловіки там живуть в середньому довше - 67,6 року. Але, порівняймо з країнами 3 дуже високим розвитком: у Чехії жінки живуть 81,6 року, чоловіки - 75,9; у Словаччині жінки - 80, чоловіки - 77,2 року; майже такі самі показники і в Румунії; з Польщею відставання на 5,5 року - жінок і 7,5 року чоловіків.

«В Україні з’явилося абсолютно нове поняття «раптова бідність», з яким нам раніше стикатися не доводилося. Вплинули на це анексія Криму, бойові дії на сході й майже 2 мільйони вимушених переселенців. Більшість із них ще вчора мали все необхідне - житло, роботу, чітко визначений соціальний статус і були самодостатніми. Та миттєво втратили все й перетворилися фактично на біженців. I це ще більше загострило соціальні проблеми, яких й до того в нас було чимало $[563] \gg$.

На рисунку 10.2.11 наведені дані щодо забезпечення мобільними телефонами та Інтернетом, задоволеністю власним та суспільним життям. 


\begin{tabular}{lcc}
$\begin{array}{l}\text { Tаблиця 1. Забезпеченість мобільними } \\
\text { телесронами та інтернетом }\end{array}$ \\
\hline & Інтернет-користувачі, \% & Мобільні телефони, на 100 осіб \\
\hline Чехія & 81,3 & 129,2 \\
\hline Польща & 68,0 & 148,7 \\
Словаччина & 85,0 & 122,3 \\
\hline Угорщина & 72,8 & 118,9 \\
\hline Румунія & 55,8 & 107,1 \\
\hline Болгарія & 56,7 & 129,3 \\
\hline Грузія & 45,2 & 129,0 \\
\hline Туреччина & 53.7 & 96.0 \\
\hline Україна & $\mathbf{4 9 , 3}$ & $\mathbf{1 4 4 , 0}$ \\
\hline Молдова & 49,8 & 108,0 \\
\hline
\end{tabular}

\section{Таблиця 2. Задоволеність власним життям, \%}

\begin{tabular}{l|c|c|c|c|c|c|c|c|}
\hline & Освітою & $\begin{array}{c}\text { Охороною } \\
\text { здоров'я }\end{array}$ & $\begin{array}{c}\text { Рівнем } \\
\text { життя }\end{array}$ & Роботою & Безпекою & Свободою вибору & Загальний \\
індекс
\end{tabular}

\section{Таблиця 3. Задоволеність суспільним життям, \%}

\begin{tabular}{|c|c|c|c|c|c|c|}
\hline & $\begin{array}{c}\text { Місцевим } \\
\text { ринком праці }\end{array}$ & $\begin{array}{l}\text { Можливостями } \\
\text { дозвілля }\end{array}$ & $\begin{array}{l}\text { Місцевоюо } \\
\text { владою }\end{array}$ & $\begin{array}{l}\text { Правовоюо } \\
\text { системою }\end{array}$ & $\begin{array}{l}\text { Захистом } \\
\text { довкілля }\end{array}$ & $\begin{array}{l}\text { Центральною } \\
\text { владою }\end{array}$ \\
\hline Чехія & 39 & 14 & 89 & 45 & 67 & 44 \\
\hline Польща & 25 & 9 & 86 & 42 & 51 & 21 \\
\hline Словаччина & 12 & 11 & 81 & 26 & 38 & 28 \\
\hline Угорщина & 23 & 9 & 80 & 42 & 46 & 28 \\
\hline Румунія & 22 & 7 & 80 & 40 & 28 & 25 \\
\hline Болгарія & 13 & 4 & 77 & 19 & 22 & 14 \\
\hline Грузія & 5 & 18 & 74 & 37 & 30 & 25 \\
\hline Туреччина & 31 & 5 & 75 & 43 & 44 & 49 \\
\hline Україна & 9 & 16 & 76 & 4 & 13 & 8 \\
\hline Молдова & 9 & 17 & 71 & 22 & 24 & 17 \\
\hline
\end{tabular}

Джерело: Інститут демографрії та соціальних досліджень ім. М. В. Птухи НАНУ

\section{Рис. 10.2.11 Результати дослідження ІД та СД ім. М. В. Птухи НАНУ}

Джерело: [563].

Найкращий індекс людського розвитку світового рейтингу у 2017 р. зафіксований в Норвегії. Такий висновок зробили аналітики Програми розвитку 
ООН (ПРООН) щодо оприлюдненого глобального рейтингу індексу людського розвитку. Згідно рейтингових, індекс людського розвитку в Норвегії має значення 0,953; Швейцарія - 0,944; Австралія та Ірландія - 0,939 та 0,938 відповідно, а на п'ятому місці - Німеччина $з$ індексом 0,936. До десятки потрапили Ісландія, Гонконг, Швеція, Сінгапур, Нідерланди. У країнах колишнього радянського союзу найкращий показник у Естонії, де індекс становить 0,871. Він відповідає 30 місцю у загальному рейтингу. Наші західні сусіди України, до яких належать Польща, Словаччина та Угорщина, посіли 33, 38 та 45 місця рейтингу, відповідно. Росія потрапила на 49-ту позицію, а Білорусь - на 53-ту. Щодо України, то автори індексу визначили ії розвиток у 0,751. Через такий показник Україна опинилася на 88-му місці у переліку з 189 країн. На останньому місці - Нігер. Визначальними критеріями є такі показники, як тривалість життя, рівень освіти та доходів громадян [521].

Отже, усе вищевикладене дозволяє зробити висновок, що сьогодні перед Україною постали серйозні виклики, які вона має вирішити, серед яких найбільш значимими $\epsilon$ : наростаюча диспропорція між бідними та багатими; падіння довіри населення до влади різних рівнів управління, а також в особистих стосунках; прогресуюче небажання працювати легально та намагання приховати свої справжні доходи; відсутність моральних принципів щодо намагання отримати від держави соціальний захист та пільги, якщо реальне фінансове становище цього не передбачає.

Оцінювання задоволеності людини за різними сторонами іiі життєзабезпечення для визначення якості життя має безліч складнощів через наявність об’єктивних та суб’єктивних причин. Через військово-політичну обстановку в Україні постає завдання щодо оновлення існуючих методик вимірювання якості життя населення. Крім того, якість життя людина напряму пов'язана 3 рівнем соціально-економічного розвитку країни. Тому, діяльність держави у сфері соціального забезпечення має не допустити погіршення ситуації щодо рівня якості життя населення своєї країни.

Аналіз реальної ситуації із забезпечення якості життя населення України 
свідчить про наявність позитивних зрушень у частині наближення до європейських значень вітчизняних державних соціальних стандартів. Але ці зміни відбуваються надто повільний. Державні соціальні гарантії, до яких відносяться встановлені законами та іншими нормативно-правовими актами, мінімальні розміри оплати праці та пенсійного забезпечення, доходів громадян, соціальної допомоги, медичне обслуговування, розміри інших соціальних послуг не спроможні задовольнити потреби українського суспільства та створити умови для комфортного та гідного життєвого рівня. Крім того, вони слабо спрямовані щодо стабілізації процесу збіднення громадян та запобігання незахищеності й соціальної ізоляції. Особливу складність відчувають більшість пенсіонерів, вразливе населення у працездатному віці у сільській місцевості та в містах, некваліфікована робоча сила, особи 3 інвалідністю й хронічними захворюваннями та багатодітні родини.

Номінальна заробітна плата середнього та мінімального форматів дає змогу оцінити загальну кількість коштів, яку виплачують за результати праці, $\epsilon$ та залишається головним джерелом доходів працюючого населення. В Україні впродовж 2004-2019 рр. номінальна середня заробітна плата (надалі НСЗП) постійно зростала, і лише у 2000 р. вона була нижчою за прожитковий мінімум для працездатних осіб (темпи їі зростання у гривневому еквіваленті становили, відповідно, 17,3 та 17,6 рази, але у валютному - лише 3,7 і 4,0 рази). Реальна заробітна плата дає змогу визначити спроможність виплачених коштів. Для неї найбільш чутливим до падіння був період з 2009 р. до 2015 р., а причиною цього були світова фінансова криза на тлі політичної й економічної кризи у країні. У 2019 р. і середня заробітна плата, і мінімальна зросли у 2,08 та 2,9 рази, відповідно.

Зростання середньої і мінімальної заробітних плат були нижчими від рівня інфляції: у 2014 р. інфляція становила 24,9\%, а мінімальна заробітна плата (надалі МЗП) не змінювалась з 2013 р.; у 2015 р. - 43,3\%, а рівень мінімальної заробітної плати було підвищено лише на 13,1\%. Це означає, що при зростанні цін у 2013-2015 рр. у межах 68-69\% держава підвищила прожитковий мінімум 
тільки на 160 грн., а це суттєво вплинуло на купівельну спроможність реальної заробітної плати. Найнижчих рівень інфляції був у 2012 р. (становив він 99,8\%), і тоді, середня та мінімальна заробітні плати становили 274,6\% та 100,1\%, відповідно, величини прожиткового мінімуму для працездатних осіб (наділі ПМдПО), а рівень середньої та мінімальної пенсій перебував на рівні 170,4\% і 104,7\% прожиткового мінімуму для непрацездатних осіб (надалі ПМдНО).

В Україні до 2009 р. були значно нижчі за величину ПМдПО, що суперечить європейській практиці та вимогам економічної безпеки: у 2004 р. та 2005 р. розмір мінімальної заробітної плати становив лише $61,0 \%$ та $65,8 \%$, а у 2008 р. - 84,87\% рівня прожиткового мінімуму для працездатних, відповідно; у період 2017-2019 рр. це співвідношення стало відповідати 190,0\%, 211,0\% та 217,0\%, відповідно, що свідчить про скерування до європейських стандартів (ще у 2008 р. для Великої Британії та Франції становили 6,4:1 та 4,7:1, відповідно [514]).

Пенсійне забезпечення у своїй величині на початку 2000 р. було мізерне. Так, мінімальна пенсія у 7 разів була меншою від прожиткового мінімуму для непрацездатних осіб. Постановою КМУ «Про підвищення рівня пенсійного забезпечення» № 1215 від 18.09.2004 р. разом з доповненням Постановою КМУ від 27.10.2004 р. рівень виплат усім категоріям пенсіонерів мінімальної величини зрівнялася $з$ прожитковим мінімумом для непрацездатних осіб та подальших змін на зниження не зазнавав.

Різке підвищення валютного курсу в країні у 2015-2016 рр., коли долар подорожчав у 3 рази по відношенню до гривні та порівняно з початком 2014 р., рівень заробітної плати у доларовому еквіваленті «відкатився» до рівня 20042005 рр., а середня та мінімальна пенсія - зменшилась практично у 2 рази. Уповільнене зростання рівня мінімальної пенсії зберігається до середини 2019 р., і це за умов проведення пенсійної реформи.

Аналіз динаміки зміни величини ПМдПО за період 2013-2019 рр. у національній валюті та за офіційним курсом євро до гривні дозволив вияви-ти, що ПМдПО за цей період (було здійснено 6 підвищень) зріс від 1210 грн. до 1921 
грн. (перше півріччі 2019 р.), а от у валютному обчисленні - падіння із 104,3 євро (кінець 2013 р.) до 64,3 євро (перше півріччі 2019 р.), тобто, загальне зменшення становить майже 1,6 рази.

Розмір прожиткового мінімуму у цінах травня 2019 р. у розрахунку на місяць на одну особу становить 4236,85 грн., але без урахування виплат -податку на доходи фізичних осіб та військового збору, становить 3690,49 грн. А для працездатних осіб фактичний прожитковий мінімум становив 4744,71 грн., без відрахувань 3819,49 грн., для непрацездатних осіб - 3144,16 грн. [519]. Це означає, що законодавчо визначений на цей місяць загальний прожитковий мінімум у розмірі 1853 грн. занижено у 2,3 рази (або на 2384 грн.), у порівнянні 3 його фактичним значенням; для працездатних осіб зниження у 2,5 рази (або на 2824 грн.); для непрацездатних - 2,1 рази (або 1647 грн.). Такий стан свідчить про значне «недоврахування» офіційних прожиткових мінімумів для цих, а також для інших, соціальних та демографічних категорій населення. Варто відзначити, що рівень прожиткового мінімуму для України $\epsilon$ «певним компромісом» між «можливостями економічного характеру держави» та соціальними потребами іï населення, а у дійсності, величина прожиткового мінімуму повинна відображати рівень мінімального доходу, який би дозволив працівникам забезпечити середній рівень життя та нормальні умови для відтворення робочої сили (структура прожиткового мінімуму містити елементи: фізіологічний та соціальний у співвідношенні $85 \%$ до 15\%).

Необхідно зауважити, що серед головних функцій МЗП (посеред відтворювальної, стимулюючої, регулюючої, оптимізаційної) досить важливою $€$ критеріальна, що слугує формуванню базового орієнтиру у встановленні рівня державної соціальної підтримки та пенсійного забезпечення населення [512]. Як відомо, мінімальна заробітна плата є основною державною гарантією, а іiі вартісне значення спрямоване на забезпечення прожиткового мінімуму. Тому, не маємо права залишати без уваги мінімальний розмір оплати праці в погодинному обчисленні. Станом на першу половину 2019 р. в Україні вона становила 25,13 грн. (або 0,90 євро) за годину роботи. Ця величина оплати є меншою за оплату 
погодинної праці в острівній державі Полінезійського архіпелагу Самоа (одна із найнижчих і становить лише 1,04 євро за годину). Так, наприклад, у Люксембурзі вона становить 12,41 євро за годину, Ірландії - 9,78 євро за годину, Німеччині 9,73 євро за годину. Щодо інших розвинених держав, то в Австралії, Новій Зеландії, Канаді, Японії та США - 11,83; 9,77; 7,55; 7,51 та 6,4 євро за годину [516].

Основною статтею споживчих витрат українців, як працездатних, так i непрацездатних, складають витрати на продукти харчування, які протягом останніх понад 10 років становили в середньому 51,4\% (у 2004 р. - 57,5\%; у 2007 p. - 58,3\%; у 2015 р. - 53,1\%). Але, відповідно до українського законодавства, «порогове» значення цього показника має становити на рівні $60 \%$, тобто досягнуті рівні витрат є близькими до критичних. Більшість країн Європи на харчування спрямовує менше $20 \%$ споживчих витрат. «На сьогодні найменше на придбання продуктів харчування витрачають у Великобританії (8,6\%), Ірландії (9,7\%) та Австрії (9,8\%), а найбільше - у країнах Балтії (Естонії, Латвії і Литві) 20,6\%; 20,4\% та 23,3\%, відповідно [507]». Варто відзначити, що показник рівня витрат на продукти харчування $є$ індикатором оцінки продовольчої безпеки держави та матеріальної забезпеченості іiі населення (за законом Енгеля: рівень життя особи - обернена залежність від частки витрат на продукти харчування). Навіть певні відчутні зростання середніх заробітних плат і пенсій у період 20172019 рр. не змінили цієї ситуації на краще, і витрати на продукти харчування цих категорій українського суспільства надалі залишились на рівні 86-94\%. Відповідь на це потрібно шукати у розбалансованості міжгалузевих відносин.

Протягом останніх років статистичні дані фіксують одноманітне харчування населення України [499], коли енергетична цінність раціону, що є реальним, забезпечується вуглеводами та рослинними жирами, і свідчить це про харчову незбалансованість (суттєво менше споживається м'яса (майже 25\%), фруктів і ягід (понад 50\%), а риби і морепродуктів (майже 80\%), що позначалося на загальній калорійності споживаних продуктів, порівняно з 1990 р., менше на 
$18 \%)$.

Постановою КМУ «Про затвердження наборів продуктів харчування, наборів непродовольчих товарів та послуг для основних соціальних i демографічних груп населення〉 № 780 від 11.10.2016 р. були затверджені переглянуті та нові норми споживчого кошика (старі діяли з квітня 32000 р.) [525]. Так, мінімальний продуктовий кошик за новими нормами для працездатних осіб у 2018 р. та 2019 р. становив 1662,0 і 1787,0 грн., відповідно (або 90,0\% та 93,0\% величини ПМдПО); для непрацездатних осіб - 1326,0 грн. та 1466 грн. (або 93,0\% та 93,7\% ПМдНО). Щодо енергетичної цінності «середньодобового набору продуктів харчування» непрацездатних осіб, то вона зросла лише на 63,9 ккал. Це означає, що пересічний пенсіонер може «збільшити» свій щоденний раціон на таке - додаткових 18 г макаронів, або 25 г вареної ковбаси, або 24 г пшеничного хліба, або 100 г молока. Фактично вибір припадає на більшу кількість споживання хліба і картоплі при зменшенні в м'яса та риби й морепродуктів - на 0,34 кг та 0,5 кг, відповідно.

Українською владою у попередні роки здійснювалося адміністрування рівня цін на обмежений перелік соціально захищених продуктів харчування. Але у вересні 2016 р. (Постанова КМУ № 656) були «відпущені» ціни на вищеозначені «регульовані» продукти, що спричинило суттєве зростання цін на них - від 17\% до 21\% [530]. Причиною цього стало подальше здешевлення національної валюти, посилення фіскального тиску, неефективність системи державного контролю. У червні 2017 р. відбулося зростання цін на 19 позицій соціально захищених продовольчих товарів (із 23). Але Уряд з 1 липня 2017 р. своєю Постановою $з$ метою «створення «нормальних умов для вітчизняних виробників та подальшого розвитку бізнесу агропромислової галузі» остаточно скасував регулювання їх ціноутворення, навіть не зваживши на готовність України до того, чи зможуть економічні закони реально диктувати правила на ринку продуктів харчування.

Аналіз вартості житлово-комунальних послуг за період 2004-2019 рр. вказує, що вони зросли майже у 30 разів, а найбільше зростання відбулося після 
2014 р. Так, вартість природного газу у 2013 р. за умов середньорічного споживання до $2500 \mathrm{~m}^{3}$ [504] (найбільш властиве для домогосподарств пенсіонерів) становила 0,7254 грн. за $1 \mathrm{~m}^{3}$ та 1 кВт. год. електроенергії коштувала 0,2802 грн. Така вартість енергоносіїв дійсно була у 8 разів меншою за європейські ціни [507]. Але, починаючи з 2014 р., їхнє зростання почалось шаленими темпами. Крім того, Урядовими рішеннями були переглянуті норми споживання для населення у випадку відсутності лічильників обліку, законодавчо забезпечено комерційний облік послуг із постачання теплової енергії, гарячої води, централізованого водопостачання. Усе це та фінансова неспроможність населення призвели до заборгованості за надані житловокомунальні послуги на початку 2019 р. у сумі 69,4 млрд. грн., яка липня цього ж року зменшилась до 57,2 млрд. грн.

Державні витрати на охорону здоров'я 3 кожним наступним роком знижуються, а приватні навпаки - зростають. «На пацієнтів вже накладено неймовірний тягар витрат на власне лікування (понад 60\% загальних витрат), унаслідок чого пролонгується не лише подальше зубожіння значної частини населення, але й відбуваються суттєві втрати людського потенціалу, які вражають увесь цивілізований світ - щорічно через низькі якість та доступ-ність медичної допомоги українців фізично меншає на 200-300 тис. осіб [499]»

Середня і мінімальна пенсії у гривневому еквіваленті за період 2004-2019 pp. зросли у 15,9 рази та 10,9 рази, відповідно, а от за приведенням за обмінним курсом НБУ до євро зростання становило лише 3,4 рази та 2,4 рази, відповідно. Порівнюючи зміни цих двох видів пенсій у 2012-2013 рр. та рівнем 2019 р., бачимо, що відбулось фактичне їх знецінення в 1,37 рази та 1,73 рази, відповідно.

Важливим економічним показником $є$ коефіцієнт заміщення доходу, тому що саме на його основі Міжнародна організація праці, а не на прожитковому мінімумі, рекомендує будувати свої пенсійні системи при нормативному значенні не нижче 40\% [541]. Так, середнє значення цього коефіцієнта в країнах ЄC становить 70,9\%, а в Україні - 35\%. Негативна динаміка його зниження відбулася з 2015 р. і до нині. Навіть заходи щодо стабілізації пенсійної реформи 
2017 р. зниження не зупинило. Це означає, що практично відсутня можливість на загальнодержавному рівні компенсувати втрачені працівниками заробітки на мінімально необхідному рівні. Ситуація щодо наповнення пенсійного бюджету свідчить про невтішні прогнози, і не лише щодо його постійного зменшення, але і щодо загроз функціонування чинної системи пенсійного забезпечення.

Якщо порівняти результати, які досягла Україна у соціальній сфері, із вимогами Стратегії Міжнародної організації праці щодо соціального забезпечення для всіх», то «Україна в горизонтальному вимірі - «швидке впровадження мінімальних рівнів соціального захисту...»- формально їх досягла [550]. А от такі основні гарантії, як доступ до першочергових необхідних видів медичних послуг та основні гарантовані доходи для осіб похилого віку i осіб, що мають економічно активний вік, і не здатних одержувати достатній дохід через хворобу, безробіття, вагітність та пологи чи інвалідність так і не забезпечуються повною мірою.

У 2020 р. Україна посіла 63 місце у загальному рейтингу за величиною індексу соціального прогресу (Social Progress Index). Усього оцінені 163 країни. Показник цього індексу України становив 73,38 бали проти 66,97 білів та 80 позиції рейтингу у 2019 р. (середнє значення індексу серед усіх досліджуваних країн - 64,24 бала). «У 2019 р. група країн із дуже високим рівнем життя i помірно високою якістю життя скоротилася з 104 до 71. Проте Україна показала значно гірші результати порівняно з іншими країнами за показниками очікуваної тривалості життя після 60 років (117-те місце серед 163 країн), а також відстає за низкою інших показників. Для довідки: індекс соціального прогресу розробив професор Гарвардської школи бізнесу та Массачусетського технологічного інституту. Даний індекс вимірює ступінь забезпеченості країни соціальними $і$ екологічними потребами населення за 54 індикаторами. Дослідження публікується щорічно некомерційною організацією [568].

Отже, аналіз ситуації щодо забезпечення рівня та якості життя населення України свідчить про наявність позитивних зрушень в частині наближення значень українських державних соціальних стандартів до європейських. Але це 
відбувається досить повільно. Державні соціальні гарантії (мінімальні розміри оплати праці, пенсійного забезпечення, доходів громадян, соціальної допомоги, доступу до основних медичних послуг, розміри інших соціальних послуг» не спроможні задовольнити потреби щодо створення комфортного й гідного життєвого рівня та слабо спрямовані на запобігання збіднення, незахищеності та соціальної ізоляції через відсутність належного фінансового бюджетування.

Однією з головних функцій держави щодо проведення соціальної політики має бути іï спрямовання на забезпечення умов життєдіяльності людини, реалізацію та розвиток її як інтелектуального так і професійного потенціалу. Реалізувати це можлива за рахунок системи соціального захисту та відповідного фінансове забезпечення, що здійснюється за рахунок державних бюджетних коштів.

Найбільше державних витрат на соціальний захист та сферою охорони здоров'я спрямовується на рівні 58,9\% у Данії, 58,8\% у Німеччині, 57,3\% у Фінляндії, 56,3\% у Норвегії. По країнах СС у загальному, то на соціальний захист направляється до 54,9\% усіх державних коштів [565]. Світові тенденції вплинули на економіку європейських держав, але скорочення видатків торк-нулося інших сфер, а щодо соціальної сфери, то тут спостерігається динаміка зростання державних видатків на соціальні потреби. Це має логічне пояснення, бо у період кризи зростає кількість населення, яке потребує соціальної допомоги, а також уряди через соціальну допомогу намагаються збільшити внутрішній споживчий попит для покращення економічної ситуації в країні.

Україна має розгалужену систему соціального захисту населення. За роки незалежності ця система була доповнена різноманітними соціальними програмами та допомогами. Це дало змогу охопити більшість населення країни різними формами соціального захисту, але при цьому збільшило навантаження на державні фінанси. Але варто зазначити, що в умовах економічних та фінансових криз ці фінанси не спроможні забезпечити бездефіцитне фінансування потреб системи соціального захисту. Розмір соціальних виплат в Україні, як свідчать попередні дослідження, є низькими, а сама система 
соцзахисту перестала бути ефективною щодо іï головного призначення зменшення рівня бідності та скорочення нерівності у доходах, а також щодо підвищення якості життя населення. Усе це може створити реальні загрози для національної безпеки України через можливість соціальних вибухів.

Соціальні видатки у державних витратах завжди посідали провідне місце, а основним джерелом фінансування системи соціального захисту є бюджет країни (державний та місцевий). В Україні спостерігається динаміка зростання видатків держбюджету на соцзабезпечення та охорону здоров'я (табл. 10.2.5).

Таблиия 10.2.5

\section{Динаміка та структура соціальних видатків у Зведеному бюджеті України}

\begin{tabular}{|c|c|c|c|}
\hline \multirow{2}{*}{ Piк } & \multicolumn{3}{|c|}{ Видатки } \\
\cline { 2 - 4 } & загальні & $\begin{array}{c}\text { на соціаль- } \\
\text { ний захист } \\
\text { та забезпе- } \\
\text { чення }\end{array}$ & $\begin{array}{c}\text { на } \\
\text { охорону } \\
\text { здоров'я }\end{array}$ \\
\hline 1996 & 7284,8 & 4105,6 & 3179,2 \\
\hline 1997 & 9529,0 & 5607,7 & 3921,3 \\
\hline 1998 & 8094,0 & 4227,0 & 3867,0 \\
\hline 1999 & 7955,8 & 4147,1 & 3808,7 \\
\hline 2000 & 10873,4 & 5985,2 & 4888,2 \\
\hline 2001 & 16030,7 & 8332,8 & 7697,9 \\
\hline 2002 & 22657,5 & 12643,9 & 10013,6 \\
\hline 2003 & 23090,3 & 12219,7 & 10876,6 \\
\hline 2004 & 30194,5 & 18113,1 & 12081,4 \\
\hline 2005 & 54055,2 & 38674,9 & 15380,3 \\
\hline 2006 & 58337,4 & 39985,2 & 18352,2 \\
\hline 2007 & 72881,8 & 47892,1 & 24989,7 \\
\hline \multicolumn{3}{|c}{ Джерело: }
\end{tabular}

\begin{tabular}{|c|c|c|c|}
\hline \multirow{2}{*}{ Рік } & \multicolumn{3}{|c|}{ Видатки } \\
\cline { 2 - 4 } & загальні & $\begin{array}{c}\text { на соціаль- } \\
\text { ний захист } \\
\text { та забезпе- } \\
\text { чення }\end{array}$ & $\begin{array}{c}\text { на } \\
\text { охорону } \\
\text { здоров'я }\end{array}$ \\
\hline 2008 & 107629,6 & 74069,7 & 33559,9 \\
\hline 2009 & 115339,9 & 78775,4 & 36564,5 \\
\hline 2010 & 149280,2 & 104534,7 & 44745,3 \\
\hline 2011 & 154396,4 & 105434,7 & 48961,7 \\
\hline 2012 & 183760,8 & 125306,9 & 58453,9 \\
\hline 2013 & 206631,3 & 145062,6 & 61568,7 \\
\hline 2014 & 195038,3 & 137993,6 & 57044,7 \\
\hline 2015 & 247331,2 & 176339,8 & 70991,4 \\
\hline 2016 & 333739,2 & 25830,7 & 75408,5 \\
\hline 2017 & 388154,1 & 285761,7 & 10292,4 \\
\hline 2018 & 425215,6 & 309363,6 & 115852,0 \\
\hline 2019 & 450147,2 & 321141,6 & 129005,6 \\
\hline
\end{tabular}

1) [495] - Бюджетний моніторинг (період 1996-2016 pp.) : сайт. URL: https://www.ibser.org.ua/publications/monitoringcategories/richnyy (дата звернення: 20.05.2021);

2) [518] - Міністерства фінансів України (період 2017-2019 рp.) : сайт. URL: https://mof.gov.ua/uk/statistichnij-zbirnik (дата звернення: 20.05.2021).

Дані таблиці 10.2.5 свідчать про те, що соціальні видатки за період, що аналізувався, зросли 31996 р., коли становили 7284,8 млн. грн., до 2019 р. до величини 450147,2 млн. грн., тобто зростання становить 62 рази. Частки видатків, які направляються на фінансування програм соціального захисту та 
соціального забезпечення, зазнають поступового зростання з кожним роком, так, якщо у 1996 р. вони становили 56,4\% загальної величини соціальних видатків, то вже у 2019 р. вони становили 71,3\%.

Також спостерігається щорічне зростання витрат на охорону здоров'я, але їх частка зменшилася з 43,6\% у 1996 р. до 28,7\% у 2019 р. Витрати на соціальний захист у 1996 р. становили 21,3\% усіх державних видатків, а у 2019 р. - 32,80\%. У 2013 р. була найвища частка соціальних видатків, яка склала 40,85\%. Крім того, слід зазначити, що спостерігається нерівномірність у темпах зростання витрат, і пов'язано це зі змінами у системі соціального захисту, насамперед, через зростання мінімальної заробітної плати та пенсії.

В Україні фінансування соціальних видатків розподілено між державним бюджетом та місцевими бюджетами. Частина фінансових коштів, що виділяється на соціальні потреби через місцеві бюджети, формуються через міжбюджетні трансферти з Державного бюджету України. У загальній сумі трансфертів вони складають близько 36,0-42,0\%, а це означає, що є великий дефіцит місцевих бюджетів при виконанні соціальних функцій, які є делегованими їм державою. Частка фінансових ресурсів, що акумулюється у Державному бюджеті України, за своїм показником є значно. У 2002 р. 73,51\% усіх державних коштів України з врахуванням міжбюджетних трансфертів перерозподілявся через державний бюджет. У 2015 р. ця величина склала 84,86\%. Під впливом реформ останніх років, у першу чергу через процес децентралізації, можемо спостерігати зменшення частки фінансових ресурсів, що перерозподіляються саме через державний бюджет України, так у 2019 р. ця частка становила 77,39\%. Це означає, що система формування місцевих фінансів характеризується хронічним дефіцитом та слабкістю.

В Україні спостерігається щорічне зростання витрат на соціальний захист з державного бюджету України (табл. 10.2.6). 
Таблиця 10.2.6

\section{Видатки Державного бюджету України за 2008-2019 роки}

\begin{tabular}{|c|c|c|c|c|c|c|}
\hline \multirow[b]{2}{*}{$\begin{array}{c}\text { Видатки згідно з } \\
\text { функціональною класифікацією }\end{array}$} & \multicolumn{2}{|c|}{2009 p. } & \multicolumn{2}{|c|}{2011 p. } & \multicolumn{2}{|c|}{2013 p. } \\
\hline & $\begin{array}{l}\text { млн. } \\
\text { грн. }\end{array}$ & $\begin{array}{c}\text { частка, } \\
\%\end{array}$ & \begin{tabular}{l|} 
мЛн. \\
грн.
\end{tabular} & $\begin{array}{c}\text { частка, } \\
\%\end{array}$ & $\begin{array}{l}\text { млн. } \\
\text { грн. }\end{array}$ & $\begin{array}{c}\text { частка, } \\
\%\end{array}$ \\
\hline Загальнодержавні функції, з них: & 24850,4 & 10,25 & 39996,6 & 11,99 & 50101,1 & 12,4 \\
\hline обслуговування боргу & 9038,7 & 3,73 & 23134,4 & 6,94 & 31677,1 & 7,9 \\
\hline оборона & 9663,3 & 3,99 & 13241,1 & 3,97 & 14843,0 & 3,7 \\
\hline $\begin{array}{l}\text { громадський порядок, безпека та } \\
\text { судова влада }\end{array}$ & 24159,2 & 9,97 & 32514,3 & 9,75 & 39190,9 & 9,7 \\
\hline охорона навкол. середовища & 1824,3 & 0,75 & 3008,4 & 0,90 & 4595,0 & 1,1 \\
\hline житлово-комунальне господар. & 270,6 & 0,11 & 324,2 & 0,10 & 96,9 & 0,0 \\
\hline охорона здоров'я & 7534,9 & 3,11 & 10223,9 & 3,07 & 12879,3 & 3,2 \\
\hline духовний та фізичний розвиток & 3216,7 & 1,33 & 3830,4 & 1,15 & 5111,9 & 1,3 \\
\hline освіта & 23925,7 & 9,87 & 27232,7 & 8,17 & 30943,1 & 7,7 \\
\hline $\begin{array}{l}\text { соціальний захист та соціальне } \\
\text { забезпечення, з них: }\end{array}$ & 51517,6 & 21,25 & 63540,2 & 19,05 & 88547,3 & 21,9 \\
\hline - соціальний захист пенсіонерів & 47912,8 & 19,76 & 58317,1 & 17,49 & 83233,6 & 20,6 \\
\hline економічна діяльність & 33294,3 & 13,73 & 44771,6 & 13,43 & 41299,2 & 10,2 \\
\hline міжбюджетні трансферти & 62180,1 & 25,65 & 94875 & 28,45 & 115848,3 & 28,7 \\
\hline Усього & 242437,2 & 100,00 & 333459,5 & 100,00 & 403456,0 & 100,00 \\
\hline \multirow{2}{*}{$\begin{array}{c}\text { Видатки згідно } 3 \\
\text { функціональною класифікацісю }\end{array}$} & \multicolumn{2}{|c|}{2015 p. } & \multicolumn{2}{|c|}{2017 p. } & \multicolumn{2}{|c|}{2019 p. } \\
\hline & $\begin{array}{l}\text { млн. } \\
\text { грн. }\end{array}$ & $\begin{array}{c}\text { частка, } \\
\%\end{array}$ & $\begin{array}{l}\text { млн. } \\
\text { грн. }\end{array}$ & $\begin{array}{c}\text { частка, } \\
\%\end{array}$ & $\begin{array}{l}\text { мЛн. } \\
\text { грн. }\end{array}$ & $\begin{array}{c}\text { частка, } \\
\%\end{array}$ \\
\hline Загальнодержавні функції, з них: & 103116,7 & 17,9 & 142492,7 & 17,0 & 164358,1 & 15,3 \\
\hline обслуговування боргу & 84505,4 & 14,6 & 110456,1 & 13,2 & 119231,2 & 11,1 \\
\hline оборона & 52005,2 & 9,0 & 74346,2 & 8,9 & 106624,1 & 10,0 \\
\hline $\begin{array}{l}\text { громадський порядок, безпека та } \\
\text { судова влада }\end{array}$ & 54643,4 & 9,5 & 87850,5 & 10,5 & 142375,9 & 13,3 \\
\hline охорона навкол. середовища & 4052,9 & 0,7 & 4739,9 & 0,6 & 5841,2 & 0,5 \\
\hline житлово-комунальне господар. & 21,5 & 0,0 & 16,9 & 0,0 & 106,9 & 0,0 \\
\hline охорона здоров'я & 11450,4 & 2,0 & 16729,4 & 2,0 & 38518,0 & 3,6 \\
\hline духовний та фізичний розвиток & 6619,2 & 1,1 & 7898,1 & 0,9 & 10007,1 & 0,9 \\
\hline освіта & 30185,7 & 5,2 & 41297,3 & 4,9 & 51624,3 & 4,8 \\
\hline $\begin{array}{l}\text { соціальний захист та соціальне } \\
\text { забезпечення, } 3 \text { них: }\end{array}$ & 103700,9 & 18,0 & 144478,9 & 17,2 & 218665,6 & 20,4 \\
\hline - соціальний захист пенсіонерів & 94811,6 & 16,4 & 133458,6 & 15,9 & 181800,0 & 17,0 \\
\hline економічна діяльність & 37135,4 & 6,4 & 47000,1 & 5,6 & 72400,9 & 6,8 \\
\hline міжбюджетні трансферти & 173979,9 & 30,2 & 272602,9 & 32,5 & 260339,7 & 24,3 \\
\hline Усього & 576911,2 & 100,0 & 839452,9 & 100,0 & 1070861,8 & 100,0 \\
\hline
\end{tabular}

Джерело:

1) [495] - Бюджетний моніторинг (період 1996-2016 pp.) : сайт. URL: https://www.ibser.org.ua/publications/monitoringcategories/richnyy (дата звернення: 20.05.2021);

2) [518] - Міністерства фінансів України (період 2017-2019 рp.) : сайт. URL: https://mof.gov.ua/uk/statistichnij-zbirnik (дата звернення: 20.05.2021).

Протягом 2004-2009 рр. витрати на соціальний захист та соціальне 
забезпечення збільшилися майже у 4,3 рази (або на 36360,1 млн. грн.): з 12157,5 млн. грн. у 2004 р. до 51517,6 млн. грн. у 2009 р.; протягом 2009-2019 рр. - ще у 4,3 рази (з 51517,6 млн. грн. до 218665,6 млн. грн. у 2019 р.). Значне зростання спостерігається тоді, коли відбувалися зміни у законодавстві України щодо «розширення видів соціальних допомог або збільшення їх розмірів, так частка цих витрат збільшилася з 18,0\% у 2015 р. до 24\% у 2019 р. у державному бюджеті України. Особливістю фінансування цього напряму у нашій державі $є$ те, що майже усі вони спрямовується на виплату пенсій та покриття дефіциту Пенсійного фонду України, а це має негативний вплив на розмір виплат на фінансування інших соціальних функцій держави, які є гарантованими.

Витрати, що спрямовуються на фінансування Пенсійного фонду України, у 2003 р. складали 28,4\% усіх видатків на соціальний захист та соціальне забезпечення. У 2014 р. він досяг рівня 94,1\%, а у 2019 р. - 83,1\%. Отже, 3 позицій фінансування на даний час головним пріоритетом у соціальній політиці держави є підвищення рівня життя пенсіонерів, але витрати на соціальний захист досягли такої величини, коли їх збереження на досягнутому рівні $\epsilon$ серйозною фінансовою проблемою для бюджету країни. Це негативно позначається на перерозподілі фінансових ресурсів для інших соціальних цілей, які теж мають значимість - це соціальне фінансування сфер охорони здоров'я, освіти, культури та економічне фінансування розвитку економіки країни.

Протягом 2002-2019 рр. частка соціальних видатків через фінансування за рахунок Державного бюджету України коливається у межах 40-65\%, а 3 місцевих бюджетів - у межах 35-60\%. А от у розрізі функціонального фінансування соціальних видатків, то спостерігаються структурні зміни: у 2019 р. найбільшу частку займає «Соціальний захист пенсіонерів», яка становить 83,1\% (проти 92,4\% у 2018 р.) усіх фінансових ресурсів. При цьому структура соціальних видатків місцевих бюджетів $є$ більш рівномірною.

Протягом 2000-2019 рр. склалася тенденція стійкості до зниження питомої ваги власних та закріплених доходів місцевих бюджетів: частка доходів місцевих бюджетів без урахування міжбюджетних трансфертів у 2000 р. становила 76,6\%; 
у 2003 р. вона зменшилась до 65,8\%. у 2012 р. до рівня 44,7\%. у 2015 р. до рівня $41,4 \%$, а у 2018 р. до рівня 46,8\%. Це означає, що значна частина податкових надходжень спрямовується саме до державного бюджету, а джерела фінансових ресурсів, що є закріпленими за місцевими бюджетами, $\epsilon$ незначними $\mathrm{i}$ покривають лише 50\% усіх видатків. У результаті цього місцеві бюджети та процес фінансування повноважень, що покладені на місцеві громади, занадто залежить від дотримання графіків переказу коштів та від повноти обсягів надходжень міжбюджетних трансфертів.

Загальний розмір коштів, які виділяються місцевим бюджетам, зростає: у 2002 р. вони становили 9039 млн. грн., то у 2019 р. вже 260174,2 млн. грн. Тобто, місцеві бюджети є сильно залежними від коштів, що надходять 3 державного бюджету України,. Крім того, ці суми зростають з кожним роком. Це зростання пов'язано 3 щорічним зростанням розміру соціальних допомог та кількості їх одержувачів через наявність об'єктивних причини. У першу чергу, через зменшення кількості народжених дітей та значну кількість переселенців 3 окупованих територій, які не оформили та не отримують соціальні допомоги. Варто відзначити, що з 2015 р. спостерігається зменшення кількості отримувачів соціальних виплат за більшістю видами соціальних допомог. Такі зміни відбулися через збільшилася кількість малозабезпечених домогосподарств, яким надавалася соціальна допомога. У 2013 р. кількість таких домогосподарств становила з 453376 одиниць, у 2015 р. вона зросла до 826131, а у 2018 р. до 874753 одиниці [546]. Це свідчить про зростанням показників бідності у наслідок погіршення соціально-економічного становища населення в останні роки.

За рахунок власних коштів місцевих бюджетів у 2008 р. покривалися потреби на соціальний захист та соціальне забезпечення (без врахування витрат на охорону здоров'я) з часткою $21,45 \%$, то у 2018 р. вона склала лише 14,28\%. Основними витратами $\epsilon$ : допомоги сім'ям 3 дітьми, малозабезпеченим домогосподарствам, інвалідам 3 дитинства, дітям-інвалідам та тимчасова допомога дітям, а також надання пільг та житлових субсидій населенню. Отже, удосконалення міжбюджетних відносин та посилення адресності соціальної допомоги на засадах підвищення ефективності ії використання - це пріоритетні 
напрями для підвищення ефективності фінансової забезпеченості соцсфери.

Оцінка соціальної політики як елемента інтегрального механізму покращення якості життя населення дозволила зробити такі висновки:

1. Головним засобом реалізації цілей державної політики у галузі покращення якості життя населення має стати збалансований розвиток України, оскільки у регіонах країни склалися різні умови щодо формування засад відтворення і розвитку населення через відмінності в рівнях розвитку інфраструктури, ступеня реалізації інноваційного та підприємницького потенціалу, сприятливості екологічної обстановки, рівнях і тенденціях соціального й культурного розвитку. Крім того, розробки і затвердження нових соціальних та екологічних стандартів у формуванні якості життя людей в регіонах країни не викликає сумнівів.

2. Надання пріоритету економічному зростанню над соціальним призводить до збідніння людей та погіршення стану суспільства, а от заходи соцзахисту можуть стати дієвим фактором для сприяння сталого економічного зростання через пряму підтримку працюючого населення, розширення його можливостей, підвищення внутрішнього попиту та продуктивності праці.

3. Соціальний захист та соціальне забезпечення в Україні в умовах сьогодення є найбільшою видатковою статтею зведеного бюджету України, а загальний обсяг фінансування за нею перевищує сукупні видатки на такі соціальні сфери як охорона здоров'я, освіта та економічна діяльність.

4. Відсутність фінансових ресурсів на місцях примушує органи місцевого самоврядування фінансувати освіту, охорону здоров'я, соціальний захист, через зменшення розмір коштів, які направлені на розвиток місцевої громади, що негативно позначається на економіці громади, регіону, країни. Крім того, фінансування більшості соціальних програм покладено теж на них. Тому, 3 огляду на дефіцитність фінансових ресурсів, має особливу важливість щодо чіткого оцінювання рівня та ефективності даних програм.

Розділ 3. Стратегія формування та регулювання соціальної політики в Україні. Світові тенденції щодо інтеграції країн та формування єдиного 
соціального простору передбачають орієнтацію багатьох країн світу на використання міжнародних норм та стандартів 3 метою забезпечення економічних та соціальних прав людини. Соціальні політики різних країн суттєва відрізняються одна від другої залежно від рівня економічного розвитку, соціально-економічної кон'юнктури та національних традицій країни. На практиці виділяються три найбільш розповсюджувані моделі соціального розвитку - ліберальна, консервативна та соціально-демократична [553].

Держави, які обрали ліберальну модель соціального розвитку, намагаються забезпечити рівними можливостями всіх громадян і гарантувати мінімальний рівень достатнього існування, але при цьому знімають з себе відповідальність щодо якісного розвитку громадянина та за його перспективу соціального характеру. Фінансування соціальних витрат, у більшій ії частині, здійснюється за державний кошт. Ліберальна модель соціального розвитку реалізується в США, Великобританії, Канаді, Австралії, Японії тощо.

Основними напрямами соціальної політики США є реалізація заходів соціального характеру для унеможливлення соціального вибуху та встановлення в суспільстві соціальної справедливості, які втілюються через боротьбу держави з бідністю та здійснюється шляхом надання соціальної допомоги громадянам для задоволення своїх основних первинних потреб у результаті відсутності власних. Соціальне забезпечення США є децентралізованим і реалізується через соціальні федеральні, штатні та місцеві програми.

Державна система соціального забезпечення США складається з системи соціального страхування та системи державної допомоги: перша - передбачає фінансування соціальних програм, які націлені на відшкодування втрати заробітної плати у зв'язку з виходом на пенсію та 3 непрацездатністю або 3 безробіттям. Програми соціального страхування складаються з двох програм:

- програми соціального забезпечення: націлена на відшкодування втрати заробітної плати. Вона фінансується за рахунок податку на заробітну плату зі ставкою 7,5\% і стягується з перших 48 тис. дол. доходу. Повний розмір допомоги отримується лише тоді, коли відбувається вихід на пенсію (у випадку смерті іiі 
отримують утриманці робітника).

- програми страхування по безробіттю: отримання допомоги має право застрахований робітник, що втратив роботу з фінансуванням виплат за рахунок сплати податкового збору у розмірі 3,5\%. Ї̈̈ сплачує працедавець 3 перших 7 тис. дол. заробітку. Розмір допомоги не перевищує 50\% від заробітку робітника.

Система соціального страхування діє на державному та на рівні штатів. Федеральний уряд здійснює загальне керівництво програмами соціального страхування, а от адресності допомоги (питання щодо розмірів та строків) вирішує штат. Паралельно, на рівні штатів, функціонують програми страхування на випадок виробничого травматизму та професійних захворювань. Метою роботи системи державної допомоги є забезпечення соціально незахищеним верствам населення гарантованого доходу у «межах малозабезпеченості». На рівні штатів розмір гарантованого доходу передбачає збільшення за рахунок бюджетних коштів штатів.

Система державної допомоги складається з 4 видів програм: додаткової програми соціального забезпечення (встановлює єдиний загальнонаціональний мінімальний рівень доходу для престарілих та непрацездатних); програми допомоги неповним сім'ям 3 дітьми; програми продовольчих талонів (забезпечення населення 3 низьким рівнем доходу допомогою у вигляді продуктів); програми медичної допомоги (фінансова допомога особам, що беруть участь у першій та другій програмах). Обгрунтування соцсправедливості в США базується на вирівнюванні рівнів соціально-економічного розвитку штатів шляхом трьохрівневого регулювання: загальнодержавного, відомчого, регіонального. На першому здійснюється формування національної політики регіонального соціально-економічного розвитку держави шляхом координації та прийняття законодавчих актів; на другому - розподіл федеральних коштів, що були виділені на проведення програм соціально-економічного розвитку регіонів; на третьому - втілюються у життя напрями соціально-економічного розвитку [567].

Характерними рисами соціальної політики Великобританії є жорстка 
перевірка потреб у соціальній допомозі, обмеженість соціальних трансфертів, спрямованість на згладжування соціальної нерівності при одночасному стимулюванні трудової активності населення, посилення децентралізації управління соціально-економічним розвитком країни, перенесення значимості соціальної політики на регіональний рівень, забезпечення та підтримка мінімальних умов життєдіяльності населення як граничної межи цивілізованого існування. Особливістю соціальної політики Великобританії є гарантування своїм громадянам мінімального рівня цивілізованого існування [570]. Засобом забезпечення належного рівня життєдіяльності населення є метод прямого перерозподілу доходів (більш 40\% рівень перерозподілу ВВП через бюджетну систему держави). Соціальна допомога населенню надається через системи соціальних трансфертів (пенсії за віком, за непрацездатністю, спадкоємцю; систему пільг (при цілковитій непрацездатності, для спадкоємців та ін.); виплати за хворобу, узаконені лікарняні та декретні; компенсації тимчасової та постійної непрацездатності, у разі виробничої травми; виплати безробітним; допомога багатосімейним та ін. Фінансову базу системи створюють національні страхові внески.

Загальне управління соціальної сфери у Великобританії здійснює Департамент соціального захисту, функціональним завданням якого $\epsilon$ дослідження процесів соціального розвитку, оцінка їх тенденцій, вдосконалення заходів щодо вирішення соціальних проблем, управління наданням грошової допомоги через центральні, регіональні та міські бюро. Управління конкретних соціальних проблем здійснюють відповідні департаментами - Департамент охорони здоров'я, Департамент 3 питань зайнятості, Департамент винагород соціального захисту тощо. Держава лише здійснює контроль за діяльністю місцевих органів влади та за потреби коригує їх діяльність.

Отже, державна система соціального забезпечення держав, що обрали ліберальну модель соціального розвитку, забезпечує високий рівень обліку соціальних потреб населення у кожному регіоні країни. До переваг можна віднести повну та оперативну реалізацію програм соціальної забезпеченості, 
захист громадян від негативних соціальних ризиків, сприяння у вирішенні найгостріших соціальних проблем, що позитивно впливає на підтримку соціальної стабільності у державі. Разом з тим є певні недоліки, а саме: створення великого апарату управління; можливість використання коштів за нецільовим напрямком використання; регіональні відмінності у реалізації програм соціальної допомоги через фінансові можливості штатів; послаблення стимулу до праці через можливість отримання допомоги за декількома соціальними програмами; посилення соціальної роз'єднаності між працюючими та тими, хто отримує соціальну допомогу.

Центристський підхід грунтується на консервативній моделі соціаль-ного розвитку держави, де велика роль приділяється сім’і як базовій соціаль-ній одиниці. Фінансування відбувається за рахунок страхових внесків, що формуються на підприємців. На основі консервативної моделі здійснюють свою соціальну політику Франція, Німеччина, Австрія, Бельгія, Італія та ін.

Французька соціальна політика спрямована на задоволення потреб громадян у гідних умовах життєдіяльності, зростання рівня зайнятості населення, гарантування соціально-економічної стабільності, забезпечення рівних можливостей громадян у реалізації своїх громадянських прав, зменшення диференціації у доходах між багатими та бідними [569]. Завдання соціальної політики вирішуються через системи систем соціального забезпечення та соціального страхування: перша - передбачає дію соціальних програм, спрямованих на відшкодування втрати заробітної плати, пов’язаної з виходом на пенсію та непрацездатністю (фінансуються за рахунок податку на заробітну плату, який сплачується робітниками); друга - передбачає відшкодування втрат заробітної плати у зв’ язку з виходом на пенсію, непрацездатністю та безробіттям, але це відбувається завдяки дії соціальних програм (фінансування здійснюється через фонди соціального страхування, за які відповідають підприємці). Тобто, спрацьовує принцип децентралізації управління соціально-економічним розвитком держави.

Виділяють три рівні управління: державний (здійснюється контроль за 
дотриманням місцевими органами влади чинного соціального законодавства); регіональний (фінансування планується 3 урахуванням інтересів та потреб департаментів та комун, які дають погодження на реалізацію плану регіонального соціально-економічного розвитку); місцевий (управління соцзабезпеченням і охороною здоров'я, житлове будування, початкове та професійне навчання, охорона навколишнього середовища та ін.; фінансування за рахунок муніципальних бюджетів, які формуються доходами від муніципальної власності, податкових надходжень, державних дотацій та кредитів).

Завданням державної політики у Франції є забезпечення для регіонів держави однакового рівня соціально-економічного розвитку. Це досягається через надання державних дотацій (основною є загальна дотація функціонування. «Вона складається з трьох частин: базової (40\%), яка залежить від кількості населення регіону; урівнювальної (37,5\%), яка залежить від рівня фінансового благополуччя території; компенсаційної (22,5\%), що залежить від специфічних характеристик регіону та його ресурсних можливостей [540, с.42]».

«Поліпшення демографічної ситуації у країні, знищення абсолютної бідності, вирівнювання соціально-економічного становища населення нових $\mathrm{i}$ старих федеральних земель - це пріоритетні завдання соціальної політики у Німеччині [537, с. 271]». Вирішення цих питань опирається на систему соціальної допомоги, що регулюється Федеральним законом про соціальну допомогу. Система соціальної допомоги складається такого: допомога по бідності, допомоги різного забезпечення. «Надання соціальної допомоги у Німеччині здійснюється за федеральним принципом. Згідно 3 ним за фінансування і управління соціальною допомогою відповідають місцеві органи влади $[498$, с. 137]». Федеральне міністерство праці та соціальних питань (загальнодержавний рівні регулювання) розробляє загальнодержавні напрями соціальної політики; виконує розробку заходів, надає практичних рекомендацій, здійснює нагляд за дотриманням чинного законодавства. Для вирівнювання життєвих можливостей населення система соціальної допомоги доповнюється 
механізмом перерозподілу коштів між територіями.

Системи соціальної допомоги країн із консервативною моделлю соціального розвитку є достатньо гнучкі та спроможні адаптуватися до потреб суспільства в умовах змін соціально-політичного становища. Соціальна політика цих держав грунтується на забезпеченні рівноваги між патерналістськими заходами та адресними соціальними програмами підтримки населення. До недоліків цієї системи можна віднести поширення певної залежності населення від соціальної підтримки держави, яке призводить до зростання витрат соціального характеру та виникнення фінансових проблем щодо їх покриття. Вирішення фінансової проблеми потребує здійснення пошуку нових джерел фінансування соціальної сфери та стимулювання розвитку системи благодійної допомоги. Соціальна політика у цих країнах направлена на подолання залежності населення від соціальної допомоги та активізації щодо включення у суспільне життя. Для соціально-демократичної моделі розвитку держави у пріоритеті $є$ досягнення рівності та соціальної справедливості, яка реалізується через рівний розподіл доходів, який забезпечує усім громадянам (без урахування трудового внеску) рівень життя. Визначальна роль щодо фінансування соціальних витрат належить державі. За такою моделлю здійснюється соціальна політика у Норвегії, Фінляндії, Швеції, Ісландії, Данії та деяких інших країнах. Економіка цих країн серед інших країн Європейського Союзу (СС) є «найбільш соціально орієнтованою за критерієм частки соціальних витрат у державному бюджеті, який коливається у межах 26-39\%. За цим показником аутсайдерами є Данії та Швеції. Витрати на соціальні цілі у відсотках до ВВП становлять 39,0 та 32,8\%, відповідно. Винятком є Ісландія, де відповідний показник є значно нижчим, ніж в інших країнах Північної Свропи, та дорівнює 19,1\% [492, с. 23-24]». Особлива увага щодо вирішення соціальних проблем громадян приділяється у Норвегії. Фінансування соціальної сфери та сфери охорони здоров'я в цій країні складає третю частину від загального доходу держави.

Управління соціальним напрямом у Норвегії здійснюється на трьох рівнях: державному, регіональному та муніципальному. Міністерство здоров'я та 
соціальних справ формує основні напрями національної соціальної політики, де у межах державного регулювання соціального розвитку виконуються: «Програма регіонального розвитку Норвегії, Програми виплат пенсіонерам (після 67 років), вдовам, дітям (до 18 років), непрацездатним, по хворобі, по вагітності та пологам, щотижневі виплати по безробіттю, за виробничі травми та ін. Виконання Програм регіонального розвитку щодо вирішення соціальних проблем покладаються на обласні ради. Реалізація державних соціальних програм здійснюється соціальними службами на муніципальному рівні [566]».

Система соціального забезпечення Фінляндії спрямована на профілак-тику виникнення соціальних проблем та на забезпечення гарантованого рівня доходу й підвищення рівня добробуту іï громадян. Система управління соціальними процесами у Фінляндії має теж три рівні, але: загально-державний, провінційний та місцевий. Керівним загальнодержавним органом управління є Міністерство 3 соціальних справ і охорони здоров’я, яке визначає основні напрями соціального розвитку держави, розробляє заходи щодо їх реалізації, готує соціальні реформи, забезпечує їх виконання та здійснює координацію соціального розвитку. Провінційне управління здійснюється структурами з соціального забезпечення й охорони здоров'я, які розподіляють державні субсидії, координують i контролюють відповідну соціальну роботу місцевих органів. На місцевому рівні управління здійснюється місцевими управліннями соціального забезпечення, які розподіляють кошти та визначають регіональну соціальну політику, збирають податки та координують надання соціальних послуг громадянам.

Отже, аналіз міжнародного досвіду щодо державного регулювання соціальної безпеки в різних країнах на засадах використання різних моделей соціального розвитку держави дає змогу визначитися 3 можливостями його використання в України. Досвід ефективного соціального управління у США, скандинавських країнах, країнах Європи визначає відповідність соціальних стратегій держави офіційно затвердженій моделі соціальної держави, а це дозволяє визначити шляхи вирішення першочергових соціальних проблем та 
гармонійний розвиток суспільства.

Проблеми, що пов'язані 3 покращення якістю життя населення слід розглядати комплексно та в системі інтересів різних рівнів. Системний розгляд синтезує інтегральну ідею покращення якості життя населення та пов’язує 3 визначеними обмеженнями та перевагами розвитку у соціальній, економічній та екологічній цілісності.

Розглянемо інтереси покращення якості життя на різних рівнях:

- світовий рівень - вирішити глобальні проблеми, які пов'язані щодо такого: боротьби з бідністю; усуненням проблем гендерної нерівності; зменшенням темпів поширення соціальних хвороб; використанням енергії і ресурсів за умов збереження навколишнього середовища; забезпеченням якісною питною водою і т. і.;

- національний рівень - вирішення державницьких питань щодо такого: зростання конкурентоспроможності держави; інтелектуальний розвиток та інформованість суспільства; перетворення потенціалів, що є у наявності (серед яких інтелектуальні, транзитні, природно-ресурсні та інших), на стратегічний ресурс розвитку України;

- міжрегіональний рівень - досягнення збалансованості у розподілі валового внутрішнього продукту у результаті впливу використання природного фактору;

- регіональний рівень - формуються напрями соціально-економічного розвитку, але без урахування корпоративних механізмів розвитку.

Держава має регулювати соціальний механізм шляхом визначення певних обмежень для непередбачених процесів, які можуть відбутися у суспільстві через процеси трансформації, глобалізації та інших. Крім того, непередбачувані процеси держава теж має спрямовувати в напрямку покращення якості життя в цілому, а не окремих соціальних груп. У галузі якості життя населення функціями державної політики є:

- розробка комплексних Концепції і Стратегії покращення якості життя 
в Україні;

- визначення регіональних пріоритетних напрямів соціальноекономічного розвитку щодо поліпшення умов життя і стану населення;

- підтримка держави досліджень, які спрямовані на визначення еталонів якості життя населення на короткостроковий та довгостроковий період запровадження;

- забезпечення державного функціонування системи контролю та прогнозування змін якості життя населення;

- упровадження єдиної та обгрунтованої системи моніторингу щодо визначення якості життя населення;

- державна експертиза на відповідність стратегічній меті щодо покращення якості життя України розроблених проектів законів, державних i регіональних програм розвитку.

Владні інститути, органи регіонального і місцевого самоврядування, громадські організації та саме населення мають реалізувати Концепцію покращення якості життя в Україні. Значна увага має бути направлена на населення, оскільки його здатність, як колективу людей, працювати, у першу чергу, у напрямку покращення власних або сімейних інтересів індивідуально, а потім і спільного життя обумовлено рівнем його соціально-психологічного потенціалу (визначальним цього потенціалу $\epsilon$ прагнення до соціальних й позитивних досягнень, які повинні отримувати підтримку суспільства).

Є декілька причин, чому ідея покращення якості життя населення має бути винесена на рівень національної ідеї, це такі:

1. Формування якості життя населення на території на засадах системності (якість життя населення спільності людей певної території $\epsilon$ системним поняттям, що передбачає формування і управління процесами, які впливають на неї та не здійснюється в межах чогось одного (галузі чи сфери);

2. Репутація держави в питаннях якості життя населення (важливий фактор оскільки пов'язаний 3 конкурентоспроможністю та інвестиційною привабливості країни. Саме через це Концепція покращення якості життя 
населення має стати основою соціально-економічної політики України).

3. Ефективне використання та розвиток людського потенціалу (затребуваність науковців, освітян та інтелектуальної еліти).

Отже, в царині покращення якості життя населення метою соціальноекономічної політики України має стати формування і відтворення людського потенціалу, характеристики якого дозволять сприяти модернізації економіки і суспільства країни.

Серйозні та значні ринкові перетворення в Україні стали причиною того, що держава не може здійснювати соціальне забезпечення усіх категорій населення через обмежені фінансові можливості. Конституцією України проголошено, що Україна $є$ соціальною державою, для якої пріоритетом $є$ соціальне забезпечення осіб. В останні два десятків років ми спостерігаємо нестабільність економічної ситуації як в Україні, так і у світі. Через це нарізними проблемами сфери соціального страхування є:

1) низький рівень охоплення збіднілого населення соціальною підтримкою;

2) низька адресність допомог при наданні соціальної підтримки.

Не через збільшення державного фінансування, а шляхом трансформації політики доходів населення має вирішуватися проблема соціального захисту. Маємо змінювати Концепцію соціальної політики - від політики встановлення системи державного захисту до політики зростання доходів, оскільки спрямованість цієї політики направлена на зростання індивідуальних доходів населення, у результаті чого кожна працююча людина може за рахунок власних коштів забезпечити себе необхідними соціальними послугами. Чинне законодавство України визначило значно більше різних видів соціальних пільг, виплат та послуг, ніж це зазначено у Конституції України чи у міжнародноправових зобов'язаннях України. Це означає, що держава бере на себе додаткові зобов'язання соціального захисту та забезпечення, які не завжди мають соціальну чи економічну доцільність (за винятком привілеїв для представників певних професій або окремих соціальних груп), а також потрібного ресурсного 
забезпечення.

Отже, фінансування соціальної сфери в Україні супроводжується значною кількістю проблем й недоліків та вимагають обов'язкового втручання. Вирішення даної проблем вимагає інноваційного реформування соціальної політики. Нестабільність економічної ситуації та наявність бюджетного дефіциту стали поштовхом для керівництва країни щодо активного пошуку підходів до розв'язання проблем фінансування соціальної сфери: встановлюються й оцінюються альтернативні доходні джерела бази державного бюджету; аналізуються різні варіанти ефективного співставлення витрат i результатів фінансування видатків. Серед основних підходів до вдосконалення бюджетного наповнення та оптимального фінансування соціальної захищеності та соціальної забезпеченості є:

- розширення сфер застосування ринкових інструментів соціального захисту: підтримка діючого обов'язкового та запровадження добровільного страхування; упровадження та розвиток накопичувальних систем страхування; диференційований підхід щодо задоволення попиту на різні соціальні послуги, через механізм діяльності державних пенсійних фондів, інститутів медичного страхування;

- нетрадиційні форми залучення коштів як суб'єктів господарювання так і домогосподарств;

- розширення сфери надання оплатних соціальних послуг, що диференційовані за ознаками якості;

- стимулювання та залучення некомерційного сектора до реалізації соціальних програм.

В Україні значний рівень фінансування для забезпечення соціальних видатків не свідчить про те, що система соціального захисту населення в Україні має ефективність з точки зору доступності та якості надання соціальних послуг та допомог. Тому, постає питання щодо створення ефективної системи фінансового забезпечення соціального захисту населення шляхом її подальшого реформування. Розроблені заходи мають зменшати навантаження на бюджет й 
сприяти нормальному забезпеченню соціальних виплат з відповідних джерел належною фінансовою підтримкою.

В Україні саме від фінансових можливостей держави залежить планування бюджетних коштів на фінансування пільг окремим категоріям громадян. А через відсутність достовірної інформації про кількість осіб, які мають право на пільги, а також про їх вартість, відсутня можливість запровадження уніфікованих підходів до визначення загального обсягу видатків державного бюджету. На сьогодні відшкодування вартості наданих пільг на протязі року знаходиться у межах фінансових можливостей держави за відповідний рік. Через це якість послуг, що надаються на пільгових умовах, знижується та відбувається порушення порядку їх надання. Ці видатки плануються не на рівні органів місцевого самоврядування, яким делеговано повноваження щодо фінансування пільг, а державними органами виконавчої влади. Органи місцевого самоврядування безпосередньо здійснюють призначення та надання пільг громадянам, але подаються розраховані показники державними органами виконавчої влади. Це призводить до того, що вони не зацікавлені у будь-якій оптимізації та економії, оскільки «кінцева визначена» сума на фінансування кожного виду пільг планується через призму наявних коштів державного бюджету та практично не залежить від реальної потреби для громади.

Варто відзначити, що система пільг і соціальних виплат, які домінує у сфері соціального захисту та соціального забезпечення, $є$ непрозорою. Замість реального соціального обслуговування населення утримується потужна розгалужена структура з державних і комунальних закладів соціального захисту та соціальних служб. Складність системи соціального захисту у сфері адміністрування пільг та обліку сприяє можливим зловживанням. Громадяни мажуть без належних підстав отримати документи, що надають їм право користуватися пільгами, на які вони не мають права. Такі порушення і з боку отримувача пільги, і з боку того, хто надав такий документ, як правило, лишаються безкарними. $€$ і інша сторона цього питання, коли особи, які мають усі підстави для отримання пільг, ними не користуються з різних об'єктивних та 
суб’єктивних причин.

Система надання пільг створює проблеми для підприємств, які надають такі послуги. 3 організаційної точки зору надання пільг зводиться до звичайного відшкодуванні витрат підприємствам, які надають певні послуги пільговим категоріям громадян. При чому, вартість наданих таких послуг, як правило, залежить від політики тарифного формування надавачів послуг без урахування державного регулювання розрахункової вартості пільги.

Реалії сьогодення передбачать, що соціальну політику не можна розглядати окремо від глобальних змін і глобальних викликів. Оскільки від таких викликів залежить загальний соціальний та економічний прогрес і безпека держави. Поглибленням соціальної нерівності, ризики бідності й соціального відторгнення, соціальні та військові конфлікти, погіршенням стану довкілля, є глобальними проблеми розвитку, які неможливо розв’язати без об’єднання зусилля всього суспільства. Створюючи власну стратегію розвитку, яка полягає в інтеграції до ЄС, Україна повинна ясно усвідомлювати як свої можливості, так і зовнішні загрози. В таких умовах, головною ідеєю соціальної політики має залишатися прагнення до більшої справедливості суспільства та забезпечення сталого розвитку економіки. Для іï створення необхідна грамотна та дієва соціальна політика. Саме завдяки реалізації заходів соціальної політики проходить затвердження принципів соціальної рівності та справедливості в рамках соціально-орієнтованої ринкової економіки.

Отже, головним та важливим кроком на шляху до вдосконалення системи соціального захисту населення має бути:

1) конкретизація та направленість. А можливо зробити тільки на локальних рівнях управління, до яких відносяться рівні областей та районів, де реально можна визначити реальну потребу людини;

2) запровадження прогресивних економічних реформ як внутрішніх так i зовнішніх змін. Прогресивні зміни економічного характеру $\epsilon$ важливим фактором розвитку держави. До них можна віднести рівноправне існування різних форм власності; лібералізація цін; свобода підприємницької діяльності; 
вільний вибір виду прикладання трудових зусиль; урегулювання оплати праці, яка має стати базою для формування зовсім нової соціально-економічної та демографічної ситуації;

3) вироблення адекватного та ефективного механізму соціального забезпечення населення;

4) соціальна політика має розглядатися у контексті глобальних змін і глобальних викликів. Це пов'язано з тим, від цих викликів напряму залежить загальний соціальний й економічний прогрес, а також безпека держави. Соціальна нерівність, ризики бідності та соціального відторгнення, соціальні та військові конфлікти, погіршення стану довкілля, які поглиблюються, відносяться до глобальних проблем розвитку, але їх не можна розв'язати без спільних зусиль всього світового суспільства;

5) розробка власної Стратегії соціального розвитку України, яка грунтується на засадах інтеграції до Європейського Союзу, має ураховувати чітке усвідомлення своїх можливостей та зовнішніх загроз;

6) головною ідеєю соціальної політики має бути визнано прагнення до справедливості у суспільстві та забезпечення сталого економічного розвитку (сьогодні Україна перебуває у складних умовах, що пов'язані з військовими дії на Сході країни, у результаті чого відбувається погіршенням економічної ситуації та зростання соціальної напруги. А це зводить нанівець шанси на реалізацію соціальної політики та економічний розвиток).

Отже, будь-які проблеми щодо урегулювання соціального захисту громадян - це прерогатива державної політики. Держава має вжити заходи для урегулювання питань економічного становища та гарантій соціального захисту громадян. Але маємо визнати, що сьогодні держава не готова, у першу чергу, через економічні обставини забезпечити виконання програм соціальноорієнтованого напряму. Цей «тягар ліг на плечі» органів місцевого самоврядування, які змушені вирішувати проблеми, що пов'язані з соціальним захистом населення, та шукати джерела фінансування для міських програм соціальної допомоги громадянам. Тому, першочерговим завданням є пошук 
оптимальних шляхів на місцевому рівні щодо надання соціальної допомоги та послуг. Запровадження нових соціальних програм і вдосконалення діючих спроможні забезпечити оптимізацію управлінням системою соціального захисту населення на різних рівнях та забезпечити високу якість й оперативність надання.

Оскільки якість життя населення та соціальна сфера мають взаємну узгодженість, то забезпеченість напрямів формування соціальної політики розділимо на дві складові: заходи підвищення якості життя населення та заходи удосконалення соціальної політики.

Заходи підвищення якості життя населення. Ми вже наголошували, що покращення якості життя населення в Україні має враховувати регіональні і місцеві специфіки розвитку країни. До інструментів покращення якості життя населення, які мають пріоритетне застосування, має входити

1) територіальний маркетинг. Такий вид маркетингу означає персоніфікований спосіб мислення і дій регіональних органів управління щодо взаємодії з власниками й підприємцями та спрямований на задоволення виявлених потреб населення регіону. Для цього потрібно системно вивчати стан і тенденції розвитку територій, налагодити збір достовірної інформації разом 3 соціологічними опитуваннями, яка ототожнює специфіку якості життя населення у регіоні;

2) розробка та затвердження Концепція покращення якості життя населення в Україні. Україна має вирішити складні завдання, які пов'язані 3 процесами інтегрування у різні міжнародні організації, а через це проблематика підвищення якості трудового життя відходить на задній план. Але, слід усвідомити і таке: без осмислення якісних характеристик життя людей в Україні будь-яке амбіційне соціальне, економічне та геополітичне завдання вирішити просто не можна;

3) забезпечення збалансованого розвитку регіонів у контексті покращення якості життя населення. Тут доцільно, окрім розробки Концепції 
покращення якості життя населення в Україні, вжити таких заходів:

3.1) розробка і реалізація «Регіональних програм покращення якості життя населення〉 через формування організаційно-управлінського механізму для забезпечення збереження і покращення якості життя населення в регіоні; (завдання - зростання і покращення демографічної ситуації; створення сприятливих умов для проживання та збереження здоров'я, сприяння самореалізації людей);

3.2) паспортизація та уніфікація регіонів і населених пунктів України за показником інтегральної оцінки якості життя населення для урахування в схемах розселення населення і розміщення продуктивних сил;

3.3) удосконалення методологій i методик регіональної соціальної статистики щодо обстеження домогосподарств для отримання достовірної інформації;

3.4) удосконалення міжбюджетних відносин 3 метою адекватного фінансового забезпечення;

3.5) актуалізація та розширення ролі місцевих органів влади.

На практиці реалізувати ці завдання є можливість через створення регіональних центрів, Координаційно-методичних рад 3 дослідження регіональних проблем розвитку (використати науково-дослідні та освітні установи), регіональні управління статистики і громадські об'єднання різних напрямів діяльності (соціальні, правові, екологічного та інших).

Заходи удосконалення соичіальної політики. Для досягнення європейських стандартів життя в Україні важливо здійснити виважені заходи щодо підвищення ефективності послуг соціальної сфери:

1) виконання економічно-обгрунтованих державних соціальних програм (ці програми мають бути спрямовані на вирішення найважливіших та найпріоритетних соціальних проблем регіонів на засадах забезпечення збалансованості, координації, організації належного контролю за їх виконанням);

2) поліпшення якості розробки «Стратегій регіонального розвитку»;

3) пошук новітніх нетрадиційних механізмів подолання соціальних 
проблем на територіях, які відносяться до депресивних, з метою зростання ефективності;

4) організація соціального моніторингу діяльності владних структур різних рівнів (державних органів, регіональних органів та органів місцевого самоврядування);

5) удосконалення міжбюджетних відносин шляхом розширення повноважень місцевих громад при розрахунку потреби у фінансових ресурсах для соціального захисту населення (поліпшення фінансування соціальної сфери на місцевому рівні без зміцнення фінансової бази та підвищення фінансової незалежності місцевих бюджетів малоймовірне. Цьому сприятиме розширення самостійності місцевих органів самовряднування шляхом побудови адекватної системи формування бюджетів;

6) посилення адресності соціальної допомоги та підвищення ефективності iii використання (можна досягли через розвиток інституту державних соціальних інспекторів);

7) удосконалення критерії визначення майнового стану сім’і;

8) достовірне формування на локальному рівні бази одержувачів усіх видів соціальних допомог 3 метою ii передання до загального Державного реєстру осіб, які користуються або мають право на відповідні соціальні виплати, допомоги та пільги;

9) залучення громадських організацій до соціального захисту окремих категорій населення;

10) створення ефективних систем моніторингів витрачання коштів на соціальний захист та визначення ефективності відповідного виду соціальної допомоги, послуги чи пільги.

11) реформування системи пільг через їх заміну на інші механізми соціального захисту (розв’язання має бути у законодавчій площині. Потрібно розділити поняття «пільга» на дві складові: перша - пільга, що надаються громадянам за життєвих обставин та зумовлюють необхідність особливої уваги до людини (є частиною державної системи соціального забезпечення); друга - 
пільга, що пов’язана зі службовим статусом особи чи видом її трудової діяльності);

12) проведення аудиту системи пільг, соціальних і компенсаційних виплат та їх одержувачів, що є чинними, для визначення обсягу фінансування;

13) розширення адресності надання пільг за критерієм доходності родини/особи та впорядкувати кола осіб, на яких ця пільга поширюється;

14) вилучення $з$ нормативно-правових документів положень про пільги за професійною ознакою (ці пільги не передбачають механізмів їх реалізації та визначення джерел фінансування та не відповідають принципам ринкової економіки. До таких пільг, на нашу думку, належать пільги для: народних депутатів, та членам їхніх сімей; кандидатам у Президенти України; депутатам місцевих рад; держслужбовцям; суддям; працівникам прокуратури та інші);

$15)$ розробка пропозицій для внесення змін до законодавчих актів з питань надання пільг найменш захищеним верствам населення та особам, які мають особливі заслуги перед Батьківщиною, опираючись на єдність принципів та критеріїв для визначення законодавчих нормам та нормативів споживання;

16) трансформація соціальних пільг в умовні трансферти (переведення субсидій за користування комунальними послугами на ваучери на придбання певних послуг комунальних підприємств (прямі грошові платежі у якості субсидій себе фінансово не виправдали);

17) застосування науково-обгрунтованих підходів до розрахунків державних мінімальних стандартів;

18) терміновий перегляд «Методики визначення розміру прожиткового мінімуму на одну особу та осіб, що належать до основних соціальних i демографічних груп населення» та приведення іiі у відповідність до вимог законодавства європейських держав;

19) відмовитися від використання показника «рівня забезпечення прожиткового мінімуму», оскільки він необгрунтовано занижує державні соціальні гарантії;

20) розширити види відповідальності для припинення практики 
невиконання правових норм;

21) запровадження правил підвищення мінімальної пенсії шляхом ii «ув'язки» з індексом споживчих цін для груп населення з різними доходами;

22) визначення нових правил щодо перегляду структури та вмісту споживчого кошика для його адаптації до потреб населення;

23) продовження реформування пенсійної системи шляхом розробки нормативних, організаційних та контролюючих механізмів регулювання запровадженого другого рівня;

24) запровадження нових видів джерел фінансування охорони здоров'я, які базуються на державно-приватному партнерстві, обов'язковій страховій медицині та легалізації інших джерел оплати наданих медичних послуг;

25) збільшення інвестування освіти, професійної підготовки та навчання національних трудових ресурсів протягом усього життя шляхом залучення як державних джерел фінансування, так і недержавних за узгодженими програмами професійної підготовки;

26) адаптації досвіду з реалізації соціальних регулювання країн $Є С$ в умовах України (не просте перенесення моделі, методу чи технології, а упровадження за умов доцільності, обгрунтованості, виконаної підготовки та належного фінансового забезпечення) та інші.

Отже, на сучасному етапі розробка та реалізація ефективної системи соціального захисту населення як складової соціальної політики у контексті забезпечення зростання рівня та якості життя населення є визначальним завданням для розбудови соціально-економічної моделі суспільства в Україні. Головних завданням державної соціальної політики України має бути забезпечення виваженого та якісного державного управління усіма сферами життя суспільства,а кінцевою метою побудови соціальної держави - політичного устрою, який би дозволив кожній людині відчувати себе комфортно сьогодні та упевнено завтра. Ми переконані, що вирішення цього завдання без продуманої, 
виваженої, обгрунтованої та ефективної соціальної політики неможливо.

Для розробки шляхів удосконалення соцполітики було встановлено:

1. Позитивний досвід щодо забезпечення ефективного соціального регулювання у світі дозволяє зробити висновок про те, що в Україні назріла необхідність здійснити зміни у розбудові соціальної направленості нашої держави шляхом забезпечення соціально-орієнтації економіки, підвищення значення держави у вирішенні соціальних проблем та розробці системи профілактичних заходів для унеможливлення соціальних небезпек. Застосування у системі національної безпеки України важелів унеможливлення соціальних небезпек потребує обгрунтованого визначення механізму регулювання соціальної безпеки.

2. Соціальна політика $є$ визначальним елементом внутрішньої політики держави, яка є значимою складовою загальної політики, та реалізується через соціальні програми та інші заходи соціально-економічного розвитку. В їі основі мають бути враховані відповідний рівень економічного розвитку та стану економіки, а от нехтування соціальними проблемами може причиною «соціальних вибухів», що призведуть до суттєвих економічних втрат.

3. Дослідження дозволило виявити тенденції формування, реалізації та розвитку соціальної політики в Україні, яка має зазнати інноваційного розвитку саме на регіональному рівні управління в умовах трансформаційних процесів в українському суспільстві. Департаменти соціального захисту населення обласних державних адміністрацій мають стати головним суб’єктом, через який реалізується соціальна функція держави.

4. Запропоновані зами шляхи удосконалення соціальної політики у контексті забезпечення покращення якості життя населення, на нашу думку, $є$ найвагомішими та спроможними підвищити соціальну направленість та рівень $і 1$ ефективності.

\section{ЗАГАЛЬНІ ВИСНОВКИ}

Виконане дослідження на тему «Соціальна політика як елемент інтегрального механізму покращення якості життя населення України» 
дозволило зробити наступні узагальнення:

1. Найважливішою функцією будь-якої держави світу є іï соціальна політика. Ця політика здійснюється як найрозвиненішими країнами (країнами загального добробуту або соціальними державами), так і країнами, які на початковій стадії розвитку (країни третього світу). Порівнюючи рівень соціального забезпечення в цих країнах, можемо впевнено сказати, що він діаметрально протилежний. Це свідчить про те, що моделі соціальної політики у цих країнах різні. Ці моделі не є ідентичними і у державах, що мають ефективну економіку. Тому, актуальне значення має з'ясування суті соціальної політики, iї функцій, принципів, моделей, інструментів тощо.

2. Важливість державної соціальної політики засвідчує перелік іiі напрямів: політика розподілу i перерозподілу суспільного продукту; демографічна політика; політика зайнятості та охорони праці; політика соціального забезпечення і соціального страхування; політика гармонізації соціально-економічних інтересів і забезпечення соціального діалогу. Кожен 3 зазначених напрямів має свою структуру з додаткових складових напрямів. Таким чином, перелік основних напрямів соціальної політики з його складовими свідчать про необхідність грунтовного аналізу потреб суспільства та відповідального ставлення державних органів влади до своїх обов'язків.

3. Соціальна політика є визначальним напрямком внутрішньої державної політики, мета якої формування гідних умови життя всім членам суспільства. Її завдання має бути - постійне покращення добробуту людей. Тому, і було створено систему соціального захисту та соціальних гарантій.

4. Результативність соціальної політики можна визначити за таким критерієм як рівень життя населення. Даний критерій характеризує спроможність задоволення духовних та матеріальних потреб громадянами. В Конституції України визнано, що найвищою соціальною цінністю держави $\epsilon$ людина, iї честь та гідність, життя й здоров'я, безпека та недоторканність називаються.

5. Державі реформи ігнорують практично усі найважливіші соціальні 
процеси. Крім того, досить часто приймаються популістські рішення, що посилює недовіру людей до влади.

6. Фактично зруйновані головні галузі соціального захисту людини, до яких відносяться охорона здоров’я, освіта та культура. У результаті цього населення втратило можливість отримувати соціальні послуги через їх їх переведення на платну основу. Матеріально-технічна забезпеченість за залишковим принципом призвела до ліквідації та зупинки більшості підприємств і систем життєзабезпечення.

7. Демографічна ситуація в Україні є критично. Це підтверджується погіршенням показників смертності та народжуваності, зниженням прогнозів очікуваної тривалості життя, загостренням ситуації на ринку праці через масову міграцію, посиленням нерівності у розподілі прибутків, масштабами бідності через постійне зростання цін на продукти харчування та комунальні послуги. Ситуація на Сході країни та пандемія теж внесли свій негативний внесок на демографічну ситуацію.

8. Прожитковий мінімум по факту більш ніж у 2 рази від встановленого на законодавчому рівні. Причино цього є те, що до його величини «підв’язано» понад 180 різноманітних видів виплат. До пошуку додаткових джерел видатків 3 бюджетів усіх рівнів та до перерахунку значної кількості виплат призводить будь-яке збільшення прожиткового мінімуму.

9. Першочерговими завданнями у сфері соціального захисту та соціального забезпечення мають стати - підвищення ефективності управління бюджетними коштами, що направляються на підтримку соціально збіднілих верств населення з боку держави, та подальше реформування сфери надання соціальних послуг і соціального захисту.

10. Необхідність реформування системи пенсійного забезпечення $\epsilon$ незаперечною. Це реформування має створити належні умови для такого: підвищення рівня пенсій; перерозподілу функцій між державою, роботодавцями й працюючими щодо соціального захисту громадян похилого віку на засадах раціональності; залучення нагромаджуваних пенсійних коштів для реалізації 
політики економічного зростання.

11. Реалізація стратегічного курсу України до європейських стандартів життя має грунтуватися на такому: підвищенні ефективності та якості надання соціальних послуг; створення та впровадження, у першу чергу, правових, а також організаційних умов недопущення зниження рівня життя населення.

12. Україна має намір інтегруватися у світове суспільство в умовах розвитку нових підходів до змісту соціальних відносин, яких вона має теж розвивати та дотримуватися. Свропейський Союз затвердив соціальні критерії, дотримання яких мають формувати та реалізовуватися у соціальній політиці держав:

- розширення свободи вибору способу життя, життєвих благ, можливостей отримати освіту та творчих здібностей;

- підвищення рівня матеріального добробуту та якості життя;

- покращення здоров’я та збільшення тривалості трудової активності;

- збільшення тривалості життя, посилення національної та соціальної безпеки.

У відповідності до статусу соціально-ринкової держави, дані показники мають реалізуватися через соціальні стандарти, які повинні забезпечити виконання основних соціальних завдань - задоволення потреб населення, збереження єдиного соціального простору, забезпечення соціальної рівності, концентрація матеріальних ресурсів тих напрямів соціальної політики, які $\epsilon$ пріоритетними.

13. Шляхи удосконалення соціальної політики у контексті забезпечення покращення якості життя населення, які були нами запропоновані мають, на нашу думку, мають найвагоміше значення на даному етапі соціальноекономічного розвитку України та спроможні підвищити соціальну направленість та рівень ефективності соціальної політики. 